Studies in African Linguistics

Volume 41, Number 1, 2012

\title{
MORPHO-PHONOLOGICAL LEVELS AND GRAMMATICALIZATION IN KARIMOJONG: A REVIEW OF THE EVIDENCE ${ }^{1}$
}

\author{
Diane Lesley-Neuman \\ Utrecht Institute of Linguistics (UIL-OTS)
}

\begin{abstract}
An analysis of the affixation processes and the phonological rules governing [ATR] harmony in Karimojong verbs permits the organization of derivational processes into three levels. On each level specific groups of morphemes are affixed and the resultant derived words undergo defined sets of phonological processes. On Level 1 a feature filling $[ \pm$ ATR $]$ harmony rule applies, in which the [ATR] feature spreads bi-directionally from the principal root vowel across the root and all Level 1 affixes. However, there are also localized disharmonic domains created by phonologized coarticulation effects of consonants and dissimilation rules for vowels. On Level 2, suffixation of Tense-Mood-Aspect (TMA) markers at the right edge of the verbal complex triggers [+ATR] feature spreading leftward across the derived word. On Level 3 affixation does not trigger [ATR] harmony processes, and both affix vowels and the derivational complexes to which they are added retain their [ATR] features. Some Karimojong affixes exhibit behaviors characteristic of two different levels, depending on
\end{abstract}

\footnotetext{
${ }^{1}$ Special thanks are due to David Rood, Bill Raymond, Ricardo Bermudez-Otero, Gerrit Dimmendaal, Grover Hudson, Bernd Heine, Dave Odden and Geert Booij for their critiques of portions of the manuscript; to Daniel Recasens, Karthik Durvasula and J.R. Westbury for input regarding phonetics; to Simon Peter Longoli and Oscar Okech, native Karimojong speakers, for comments on contemporary language use; to Helga Schroeder and other attendees at the $10^{\text {th }}$ Nilo-Saharan Linguistics Colloquium in Paris, and the $37^{\text {th }}$ Annual Conference on African Linguistics in Eugene, OR. Thanks are also due to the African Studies Center at Michigan State University and the U.S. Dept. of Education for awarding me a Title VI Foreign Language Area Studies fellowship, which provided financial support for my research, and to the Leiden University Phonetics Laboratory for receiving me as a guest researcher in the later stages of manuscript completion and revision.
} 
context; these affixes are proposed to be in transition between levels. The three levels are proposed to result from diachronic evolution, and their relative chronological development can be established by (1) correspondences to landmarks within the cross-linguistically attested agreement system grammaticalization cline, which groups affixes according to ordering universals, and (2) the existence of successive evolutionary cycles of frequentive morphology. A model of the morphology-phonology interface is proposed in which linguistic structure internal to the morpheme channels the spread of [ATR] features. The model provides an explanation for surface irregularities that originated at the time of areal vowel mergers in Nilotic languages (Dimmendaal, 2002).

\section{Introduction}

Karimojong is an Eastern Nilotic language with an unmarked VSO word order, and is spoken in Karamoja Province in eastern and northeastern Uganda. It is mutually intelligible with the languages of the Jie, the Dodoth, the Toposa, the Nyangatom, and the Turkana, with which it shares an $85 \%$ lexical similarity. All are part of a larger group of Tuya peoples whose migrations for better grazing lands and from population expansion were initiated more than a millennium ago from the southern portion of the Omo River valley, north of Lake Turkana. These peoples are united by the use of the root 'tuna' in expressions referring to 'human being'. Oral histories of both the Karimojong and the Turkana attest to their existence at one time as a single group (Novelli, 1985; Dimmendaal, 1983).

The focus of this paper is on [ATR] harmony patterns of the Karimojong verbal complex, the evidence they provide regarding the language's history, and a theoretical model that accounts for them. Surface forms show discontinuous harmony domains, which are problematic to mono-stratal and linear phonological models. The patterns in the data can be explained by a derivational model with three strata determined by distinct sets of phonological rules, a morphology-phonology interface that channels the spreading of features according to a morpheme-internal structure, and the identification of subsidiary processes of morpheme genesis and evolution. The three strata are proposed to represent separate stages in the historical development of the language. At issue is the behavior of the phonological component of the grammar in its interface with the morphology undergoing historical changes denoted by the term 'grammaticalization'. Phonology has remained an understudied 
aspect of the grammaticalization research program, and it is the purpose of this paper to make a contribution to this subfield.

The placement of morpho-phonological (MP) levels in historical time is carried out in three lines of argument. The first establishes the relationship between the MP levels of affixes and landmarks in the principal grammaticalization cline affecting the Karimojong verbal complex. Explanations for the small subset of exceptions are provided using comparative and internal evidence and attested processes of language change. The second line of argument relates affix order in the Karimojong verbal complex with MP levels in light of a recognized universal tendency (Bybee, 1985) to which the Karimojong case corresponds. The third builds upon the second by presenting a process of morpheme genesis and evolution across MP levels and historical time to produce successive generations of cognate structures, while proposing a historical nexus between some inflectional and derivational morphemes. Such instances of 'florescence' (Chafe, 2000) are not unprecedented in grammaticalization processes found in agglutinating languages. These arguments converge in identifying the first MP level, at least in its origin, as being the oldest historically. Phonologically most Level 1 affixes are recessive under a bidirectional root-controlled $[ \pm \mathrm{ATR}]$ harmony. The second MP level contains, in the main, affixes that are newer than those found on the first and older than the majority of those found on the third. They are suffixes that trigger a dominant leftward-spreading [+ATR] harmony process. Affixes on the third MP are inactive with regard to [ATR] feature spreading. They consist of both relatively newer affixes that are in incipient stages of phonological incorporation and older inflectional suffixes experiencing erosion and loss. Because individual affixes change levels under processes of historical evolution, and in fact can be found on more than one level during their transition, the relative chronologies of the MP levels are to be taken as general statements.

The remainder of this chapter in $\S 1.1$ provides an overview of grammaticalization theory and an explanation of the agreement system grammaticalization cline found in the Karimojong VP, during which the argument for the correspondence between MP levels and stages of the cline is presented. The discussion of inflection in light of attested universals appears in $\S 1.2$. The [ATR] harmony system is explained in $\S 2$ and a discussion of the morphological structure, its interface with phonology and word formation is carried out in $\S 3$. The phonologies of the first, second and third morpho-phonological levels are discussed in $\S 4, \S 5$ and $\S 6$ respectively. The genesis 
and diachronic evolution of frequentive morphology appear in $\S 6.4$, with comparisons to other languages in the Teso-Turkana cluster. Conclusions are presented in $\S 7$.

1.1 Grammaticalization in Karimojong. Grammaticalization is defined most broadly as the gradual process by which lexemes are transformed into grammatical forms, which likewise continue to evolve within the grammatical system. Now denoting a fully established area of linguistic research with many adherents and practitioners, it was first proposed terminologically by Meillet (1948[1912]), who claimed in L'evolution des formes grammaticales that new grammatical forms emerge through two distinct processes: through analogy, and through the transformation of an autonomous lexical word into a grammatical element. He had been preceded by Wilhelm von Humboldt (1822) who had proposed four stages in the evolution of grammatical forms. Gabelentz (1891) proposed that phonological attrition and the rise of new vocabulary result from the tension of between ease of articulation and the need for distinctiveness. Hodge (1970) used the history of Egyptian to address the diachronic relationship between morphology and syntax. The Hodge proposal was popularized and reformulated in Givón's (1971b) landmark paper, which stated "today's morphology is yesterday's syntax." This became the rallying cry for the new subfield of grammaticalization studies.

Givón's work during that decade (1971a, 1971b, 1975a, 1975b, 1976, 1977, 1979a, 1979b) set the stage for the subsequent research, mainly in what is termed syntacticization. Key was his demonstration that structures of pragmatic discourse develop into grammaticalized syntactic structure, which in turn develops into morphology. Due to phonological attrition, morphology degrades into morphophonemics until the phonetic substance of the affix is lost altogether. Givón also explained how paratactic sentence structures are transformed into clause subordination, and how two distinct verbs come to form complex verbs. Quite importantly for the description of word order change in Nilotic, his 1977 work broke down in detail the historical change in Hebrew word order from VSO to SVO.

Givón's (1979a) critique of Heine's (1976) word order typology of African languages impelled Heine to take into account the historical forces shaping language structure, embarking him on a prolific career analyzing data from African languages to develop the theory. Important highlights from his extensive publication record 
include the joint collaboration with Mechthild Reh (Heine \& Reh, 1984) in which the phonetic, phonological, morphological and syntactic aspects of grammaticalization in a diverse selection of African languages are presented. His 1986 work employed data from Ewe to show that the gradual continuum observed in grammaticalization processes is at odds with the discrete grammatical categories demanded by generative theories of syntax. In Heine, Claudi \& Hünnenmeyer (1991), data from a variety of African languages were used to argue that pragmatic and cognitive forces shape the development of grammatical categories. Heine and Kuteva (2002a) described more than 400 grammaticalization pathways. Their 2007 joint work (Heine \& Kuteva, 2007) provides an overview on the state of the art of both grammaticalization theory and language evolution. ${ }^{2}$ Interspersed with and contributing to these developments are works by other authors. A comprehensive overview is provided by Christian Lehmann's Thoughts on Grammaticalization in its various editions (1982, 1995, 2002), discussing definitions, grammatical domains, and parameters of operation. Both editions of Hopper \& Traugott (1993/2003) provide comprehensive overviews of methodological issues. Traugott and Heine (1991) produced a two-volume anthology representing the diversity of viewpoints in what had become a burgeoning field of inquiry.

The first step in a grammaticalization process occurs when a lexeme referring to a physical object or state is used metaphorically in a linguistic structure to designate more abstract content. Over time, the abstract meaning is transformed into a grammatical function, and the lexeme into a function word, leading to the eventual loss of its original meaning. Further along the evolutionary cline, it can lose its status as a function word and begin the process of forming part of the morphology of the language. Its independent status is first downgraded to that of a clitic, relegating it to a fixed position with respect to another syntactic constituent, to which it is bound syntactically, and on which it shows some degree of phonological dependence. With increased use, the limited autonomy of the clitic is lost, and the structure becomes a

\footnotetext{
${ }^{2}$ One reviewer questioned the omission of Blevins' (2004) Evolutionary Phonology from this discussion. While this author considers it to be an excellent study of the historical evolution of sound patterns and their distribution, its principal focus is on regular sound change, and is not part of the research tradition of grammaticalization. It does not address the principal thrust of the analysis in this paper: that regularity in Karimojong is circumscribed by morphology, and that irregularity arises from the phonologization of phonetic effects and the intervention of the cognitive system to preserve distinctiveness.
} 
bound morpheme. Later in the evolutionary cycle, it demonstrates increasing levels of integration into the phonological processes within the hosting word, and may combine with other morphemes into a synthetic structure while retaining some of its original phonology. Over time, the phonology of this morpheme is eroded until its segmental content is lost altogether. Simultaneous with its phonological reduction is the rise within the language of new ways to equivalently express the same concept. Word order changes may occur, or new lexemes or particles arise that may subsequently undergo other changes but which may also begin the evolutionary cycle anew. Old and new structures exist side by side in a phenomenon termed 'layering' (Hopper 1996).

The grammaticalization cline relevant to the study of the Karimojong verbal complex and its [ATR] harmony patterns is shown in (1), and involves the agreement system.

\section{(1) Agreement System Grammaticalization Cline}

independent pronoun $\rightarrow$ weak pronoun $\rightarrow$ clitic pronoun $\rightarrow$

agglutinative (affixal) agreement marker $\rightarrow$ fused agreement marker $\rightarrow \varnothing$

Excluding an initial stage of personal pronoun genesis (see Heine \& Song, 2011), it starts with the referential pronoun as an independent grammatical and phonological word. It passes through the stage in which it is phonologically weakened but still independent, on to that of a clitic. It then loses its independence completely to become attached to the verb as an agglutinative agreement affix. Phonological erosion proceeds to a point at which it fuses with other morphemes, adding semantic content such as tense, mood or aspect. The process continues until the loss of all phonological content and segmental features is complete. Karimojong, like other African languages (Tucker, 1975; Dimmendaal, 1982; Kiggen, 1983; Akinlabi, 1994), shows a variety of patterns of partial feature loss, which are considered to be transitions within the continuum of change. Among them is the de-voicing of vowels, most frequently in morphemes coding the aorist past. Other examples include the erosion of all segmental features of Tense-Mood-Aspect (TMA) markers, excepting a phonologically active [+ATR] feature, which triggers a suffix-controlled harmony 
process. Paradigms illustrating these conditions and others are presented in $\S 6.3$ example (43) and in Appendix C.

Fuss (2004) invoked the cline as a universal process in his analysis of Germanic, citing evidence from Indo-European, Basque, Semitic, Mongolian, Tibeto-Burman, Mon-Khmer, Austronesian, Uto-Aztecan and other Native American languages. Siewierska (2004: 16-74, 262) likewise presents it as such after devoting a full chapter to a cross-linguistic discussion of each stage within a typology of person marking. Lehmann (2002: 33-37) discusses the cycle as a general process occurring cross-linguistically as do Hopper and Traugott (2003:15). An incipient version of the cline was entertained by Jespersen (1922: 375-384) who, using Humboldt's agglutination theory as a point of departure, discussed it as a matter for debate among historical linguists. He evaluated it as being problematic on the surface, but having some merits and requiring further (cross-linguistic) study.

In the Karimojong case, three cycles of agreement system evolution are layered and result from successive changes in word order from VSO to SVO to VSO, as suggested by historical reconstruction in Teso-Turkana by Dimmendaal (2005) and internal evidence. Example (2) presents a model with landmark stages of word order change. It builds upon Givón's (1975b) proposal for the rise of agreement morphology from the topic-shift construction, based on evidence from African languages and English- and French-based creoles, and takes into account Karimojong forms that have arisen from the pragmatics of language use. In (2a), the emphatic form with topic shift employs a pronoun that is superfluous for the coding of person and number. The overuse of this structure leads to its re-analysis as agreement on the verb, shown in (2b). The encoding of agreement information allows the overt pronoun to be dropped without the identity of the referent being lost, shown in (2c). The pragmatic reference occurring in commands, oaths and in first and second person conversational exchanges, as well as the understood use of third person for impersonal constructions also lead to the suppression of overt pronominal referents, which is referred to in (2d). In (2e) the pressures of paradigm uniformity cause agreement morphology to lose its distinctiveness, and the segmental substance coding referents becomes eroded and lost. Identification takes place through preferred interpretation (Cole, 2009), but by necessity leads to the case of (2f), where a new pronoun arises in a different position in the sentence. 
In actuality, the phases of this model are not strictly sequential, as they often occur simultaneously within and across paradigms. New pronouns can and do arise when the distinctiveness of morphological inflections first begins to weaken, in anticipation of the subsequent erosion and loss of segmental content. The pragmatic recovery of phi features under the loss of overt information may occur in some paradigms and not in others at a given moment in the language's history. Although incremental changes in microcosm ${ }^{3}$ appear uneven synchronically, they contribute overall to the progressive evolution of the cline. This is in keeping with the strictly gradual nature of the grammaticalization continuum and of syntactic change in general noted by Meillet (1948[1912]:135), Chung (1977), and Heine and Reh (1984:15). In the opinion of these authors, the definition of discrete stages is arbitrary, despite the apparent segmentability that changes in isolation may demonstrate at any synchronic instance. Following this line of reasoning, the stages in this model are merely idealized landmarks along the gradual continuum of change.

\section{(2) Agreement System Evolution with Word Order Change}
a. Topic Shift
b. Re-Analyzed Case
c. Pro-Drop
The man, he came.
The man he-came.
(pro) he-came.
d. Pragmatic Recovery of Phi Features
NP (pro) (phi) came.
e. Erosion of Paradigm
(pro-phi) came.

\section{f. New Pronoun}

Came he(2).

In the Karimojong source material, exact matches for stages (2a) and (2b) are not found, but there are structures with the alternate SVO word order that correspond to them. Examples (3a) through (3d) are taken form Novelli $(1987: 108,110)$, while the sentences with the pronouns pre-posed as expressions of focus in (3f) and (3g) are taken from Novelli (1985: 111).

\footnotetext{
${ }^{3}$ See Lesley-Neuman (2007) for more discussion of evolutionary microstages.
} 
(3)
a. edikíno
ìnéz $\varepsilon$-twan-í
imminent.PRES 3s 3-die-s.PRES.CONT

'He is dying.'

b. adikíno ìnéz a-twan-í

imminent.PST 3s 3PST-die-s.PST.CONT

'He was dying.'

c. eriná ìkéz i-muf-éte

still $3 p \quad 3 . C L 2 .-e a t-2 / 3 p . C O N T . P R E S$

'They are still eating.'

d. erokó ìkéz ne-pón-a

not yet $3 p \quad$ NEG.3.-arrive-3p.PST.

'They have not yet arrived.'

e. apótu ìkéz to-kjen-átar ìnéz

PST.p 3p 2/3-laugh at-REFL NARR.PST.p. 3s

'They laughed at him.'

f. ìnéz á-gólókin-i ékèk

3s.FOC 3.CL2-close-A.IPFV.PST.s door

'He closed the door.'

g. aeoón à-càp-í amaá ke emèlèku

1s.FOC 1s.CL1-weed- field A.IPFV.PST.1s with hoe

'I weeded the field with a hoe.'

Remnants of Stage (2c), involving the suppression of overt pronouns, a condition often termed 'pro-drop' in the formal linguistic literature, are seen in the examples in (4). They carry Form B verbal inflections, which are generally employed with alternate word orders in present-day Karimojong [171, 150]. Expressions of cause, especially when pre-posed, accompany the alternate word order. 

a. à yakiro à yòn
à-bón-ún-já ${ }^{4}$
ló-rè
because of this
1s.CL1-come back- home
B.IPFV.PST.1/2s

'Because of this, I came back home.'
b. aní ćkàaú k?'́-jì-jòtó ki-muJ-a which after SUBJ.3p-fight-B. then.eat-B.PST.3p IPFV.PST.3p

'(Since) after they fought, then they ate.'

The examples in (5) show stage (2d), the pragmatic recovery of person and number features when they are not explicitly coded on the verb. In (5a) [512], the pronominal prefix [i-], used for habitual tense construction of Class 2 verbs, is employed with the verb [-gworo-] 'cry' to refer to [íkj̀kơ] 'child,' which is presented in the preceding clause. This prefix can alternately code second or third person, as well as singular or plural number. Reference to the preceding clause identifies the third person singular. Examples (5b) through (5e) [193] show oaths, ceremonial and socially scripted greetings, being coded ambiguously for number by their pronominal inflections, recovering this information through use in context.

a. tò-nò̀pìtè mono íkòkú, ì-gworo 2s-wear (unclear) child 2/3.CL2-cry.HAB.

'Carry the child on your back, since he cries.'

b. màata ós-pi' tà hail CL1.1-multiply in great numbers.IMP 'Hail, let us multiply in great numbers!'

c. màata ós-bárà hail CL1.1-be rich 'Hail, let us be rich!'

\footnotetext{
${ }^{4}$ In this example Novelli shows a low tone rather than a high tone on the inflectional suffix, which conflicts with the information given in the verbal paradigms and the gloss he provided.
} 
d. màata ée-málás hail CL2.1.IMP.-greeting.HAB

'Hail, let us be greeting always!'

e. màata to-məjəy

hail CL1.2- grow old.IMP.

'Hail, may you grow old!'

Examples (6a) and (6b) [471] show old imperatives from which person and number information have been lost from the erosion of the pronominal prefixes. They exemplify stage (2e).

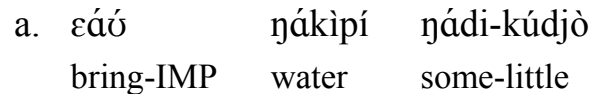

'Bring some little water!'

b. ìàutú cèn-ìté

bring that I may see

'Bring it that I may see!'

Corresponding to stage (2f), in which the free pronoun arises from the need for identification, are examples (7a) [283] and (7b) (Mantovani 1963: 51). Passive voice paradigms have uniform suffixal inflections, and their prefixes code person without number. Examples (7c) and (7d), from Novelli $(1985: 130,503)$ show what could be transitional stages in the rise of free pronouns. The verbal complexes code number on the suffix and person on the prefix. The free pronoun is not strictly necessary, but the extent and complexity of verbal paradigms in the language make this redundancy an aid to communication.
a. غ̀-d’̀n-ún-ítaè̀
ínèz
3-pinch-FREQ-A.IND.PASS.PRS.PERF $3 \mathrm{~s}$
'He has been frequently pinched.' 
b. $\varepsilon$-ram-jò

ikéz.

3.CL1-beat-A.PASS. IPFV.PRES.3. $3 p$

'They are beaten.'

c. i-jaká-tàr

íčz ${ }^{5} \quad$ adjo-kìmof

2-have-B.PRS.p PRS.PRG.IPFV.p 2p any food

'Do you have any food?'

d. í-rúkor-étè

ìcz $\mathrm{ka}$ yaı?

2-go-A.CL1.PRS.PRG.IPFV.p 2p with whom

'With whom are you going?'

Hence, the layering of agreement system morphology in Karimojong can be described as shown in (8). In (8a), the fused TMA marker [-azi] , labeled ' $\underline{\mathbf{x}}$ ', is a synthetic morpheme derived in part from a formerly post-verbal pronoun that became bound to the verbal complex. Uniformity at this stage in the historical evolution of this particular paradigm precludes it from identifying person and number, although TMA markers in other paradigms do so. A fused form carrying inflections of tense, aspect and mood, it predates the prefix labeled ' $\mathbf{y}$ ' that codes third person. As these two forms together do not completely identify the subject, the third person plural free pronoun, labeled ' $\underline{\mathbf{z}}$ ', is employed after the verb. This case contrasts with those in (8b) and (8c), in which inflections on the verbal complex fully code the identity of the subject. In (8b), TMA marker [-já], of the Form B past imperfective, may refer to either the second or first person singular;
a. $\underline{\mathbf{y}} \underline{\mathbf{x}}$
$\underline{\dot{\varepsilon}}-1 \grave{j}-\underline{a z i ̀ ~}$
3-dry in the sun-REFL.IND.FUT
$\underline{\mathbf{Z}}$
$\underline{\text { íkèz }}$
'They will dry themselves in the sun'

\footnotetext{
${ }^{5}$ Novelli used the second person singular in the expression, but it is an incorrect usage according to the Karimojong conjugation.
} 
b.

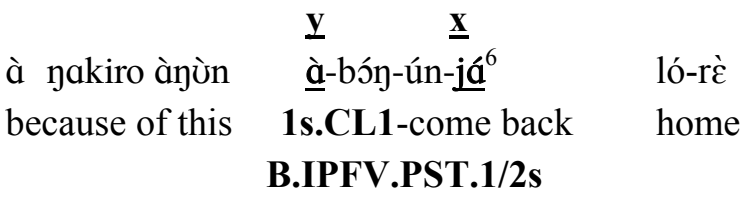

'Because of this, I came back home.'

c. $\underline{\mathbf{y}} \underline{\mathbf{x}}$

àd-bùn-ị akaaú

3s.CL2-come-PST.3s late

'He came late.'

d. $\underline{\mathbf{y}} \underline{\mathbf{x}} \underline{\mathbf{z}}$

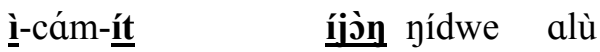

2s-want-PRS.PERF.s 2s children which

'Which children have you wanted?'

e. $\stackrel{\mathbf{y}}{\text { ì-cám-ít }} \underline{\underline{\mathbf{x}}}$

yídwe alù

2s-want-PRS.PERF children which

'Which children have you wanted?

The first person pronominal prefix [à-] clarifies the ambiguity of reference and obviates the need for an independent pronoun. Synthetic TMA marker [-i] in (8c) encodes the third person singular and the aorist past, with pronominal prefix [à-] providing identical phi feature information in the absence of a free pronoun. The minimal pair sentences in (8d) and (8e) show the free pronoun to be optionally employed when inflection on the verbal complex fully identifies the referent. TMA marker [-it] identifies a singular verbal subject, while pronominal prefix [ì-] codes the second person singular. The second person singular free pronoun [íjòn] appears in (8d), but is omitted in (8e). The two sentences are equivalent in meaning.

\footnotetext{
${ }^{6}$ In this example Novelli shows a low tone rather than a high tone on the inflectional suffix, which conflicts with the information given in the verbal paradigms and the gloss he provided.
} 
In summary, all of the TMA markers in (8) that are labeled $\underline{\mathbf{z}}$ are the new free pronouns arising under the contemporary phase of VSO word order. Those labeled $\underline{\mathbf{x}}$ are the oldest forms and correspond to the fused marker status in the Agreement System Grammaticalization Cline in (1), even though uniformity of the inflectional paradigm of the morpheme in (8a) has proceeded to a point in which all person and number feature distinctions have been lost. The fused markers are proposed to have originally been free pronouns that have passed through processes of agglutination, erosion and fusion with other morphemes in a previous period of VSO word order. Those morphemes labeled $\mathbf{y}$ constitute a set of agglutinated affixes from the cline and are relatively new. They are proposed to stem from the weakening and agglutination of formerly free pronouns during a period of SVO word order. This can be proposed with a high degree of certainty based on reconstructions within Nilotic by Dimmendaal (2005) using head and dependent marking to compare VSO and SVO Nilotic languages. Karimojong possesses an alternate SVO word order, a condition Dimmendaal notes to be an attested universal among VSO languages. This universal pattern is indicative of the historical evolution in word order, which Dimmendaal attributes to drift.

The Guide to Selected Karimojong Morphemes in Appendix A has the morphemes grouped by MP Level and specifies their corresponding phonological pro-cases. The great majority of TMA markers are found on MP Level 2, with a small number of examples distributed on Levels 1 and 3. Likewise, the majority of pro-nominal prefixes are phonologically inert and affixed on Level 3, excepting subsets inflecting the narrative and imperative moods that correspond to Level 1 . The positioning of affix types within the agreement system grammaticalization cline introduces a relative chronology into the lexical phonology model. Level 2 affixes, possessing a higher degree of phonological integration, are historically older and further along in the process of grammaticalization than the inert pronominal prefixes found on Level 3. Those TMA markers found in Level 1 are proposed to have been originally Level 2 markers that became recessive as a result of vowel mergers ${ }^{7}$. Level 1 affixes are otherwise considered to be the most highly integrated phonologically in that they are recessive in all cases, adopting the root vowel [ATR] specifications in Level 1 affixation and any dominant suffix-controlled process found on Levels 1 or

\footnotetext{
${ }^{7}$ See Dimmendaal (2002) regarding vowel mergers in Teso-Turkana.
} 
2. This may apply specifically to the narrative ${ }^{8}$ and imperative mood pronominal prefixes due to high frequency use of these forms within an oral culture (Bybee, 2001; Gerrit Dimmendaal, p.c.). Dimmendaal (1991: 293) reports the recessive behavior of narrative mood prefixes in Nyangatom, Turkana and Ateso, but fails to note it for Karimojong, despite citing Novelli (1985) as a reference.

1.2 Affix-Ordering Universals and the Karimojong Case. Among the theories proposing to account for affix ordering is 'Onion Theory' (Bybee, 1985; Wunderlich \& Fabri, 1994), so-called for its likening of inflectional morphology to the layers in an onion. Under this Theory, inflectional affixes in the verbal complex flank the verb and its derivational morphology on each side in the following order: Person-NumberTense-Aspect-VERB-Aspect-Tense-Number-Person. In Karimojong, inflectional morphemes are synthetic and therefore carry information for several types of inflection. There are differences among the numerous paradigms in the language as to what is coded distinctively by each inflection in the same position in the verbal template. This is the result of evolutionary processes in which incorporation, pressures for paradigm uniformity, and attrition occur simultaneously but variably. In addition, the balance within the template in Karimojong is not perfectly symmetrical, in that suffixal inflections often carry a richer information load and tend more frequently to be multi-syllabic than the prefixes.

This imbalance is caused by the stage in the historical continuum to which the verbal complex has developed. The agreement system grammaticalization cycle occurring simultaneously with processes of word order change in Nilotic has created the templatic structure in which the evolving prefixal and suffixal inflections surround the verb and its derivational morphology. At this point in time, the suffixal inflections are the result of fusion with other morphemes, and so differ in size and content. The balance of the template may also be a reflection of the cross-linguistic suffixal preference reported by Bybee et al. (1994). This structure characterizes the verbal complex in the languages of the Teso-Turkana cluster and is illustrated and discussed further in example (10) of $\$ 3$.

The schema provided by Onion Theory was developed with evidence from a large sample of languages. Its existence in conjunction with the well-attested process of agreement system evolution provides justification for the evolutionary model that

\footnotetext{
${ }^{8}$ Often referred to as the subsecutive mood.
} 
explains Karimojong system of person marking. An analysis of morpho-phonological levels based on [ATR] harmony rules within the scope of this model will provide an explanation for the discontinuities in the [ATR] domains in of the verbal complex. To achieve this end, the [ATR] harmony system is presented in the following section.

\section{Vowel Inventory and [ATR] Harmony System}

The cross-height vowel harmony system pairs non-low [+ATR] vowels with [-ATR] vowels of the same height. The [+ATR] vowels of alternating affixes appear in [+ATR] environments, and analogously, the [-ATR] vowels appear in [-ATR] environments. There is some disagreement in the literature as to whether the system in Karimojong has 10 or 9 vowels. Novelli (1985: 29) presented the system in the main as having 10 vowels, with each [+ATR] vowel alternating with its [-ATR] variant: i-I, e- $\varepsilon, a-a, o-0, u-\mho$; but the a-a alternation was not represented in general throughout the grammar due to his use of the orthography of Westerman and Ward (1933). Vossen, reporting on the work of Köhler (1970), distinguishes a nine-vowel system with the low vowel variants merged. Heine (1980), working without instrumental analysis, describes the two variants in Turkana as "phonetically identical, but to be distinguished on morpho-phonological grounds." However, as low vowel $[\mathrm{a}]^{9}$ alternates with [o] within a particular set of suffixes under rootcontrolled harmony processes, it appears that the vowel mergers between [a] and [a], and [a] and [o] described by Hall and Creider (1998) and Dimmendaal (2002) are well along in the data reported by Novelli. Nine-vowel systems in related languages are reported by Vossen (1982) who considers [a] to be neutral and transparent to harmony. Nonetheless, this vowel is also cited as pairing with [-ATR] vowels in some processes (Noske 2000, inter alia). A resolution to this ambiguity created by the lack of instrumental analysis is suggested by the study of vowel harmony systems with ultrasound imaging. It has been shown that the low vowel [a] in [ATR] harmony systems shows tongue root advancement in [+ATR] environments (Gick, et al 2006; Archangeli 2003), a result confirmed through careful acoustic analysis for Maa, an Eastern Nilotic language (Guion, Post and Payne, 2004). This [+ATR] vowel will be

${ }^{9}$ On the basis of personal communication with Hans Stoks, Doris Payne, Gerrit Dimmendaal, the vowel quality has been confirmed as [a]. Further instrumental study is considered to be warranted. 
represented as $[a]$ and is shown as the tenth vowel of the harmony set in parentheses. This vowel, as will be reported here, is not distinguished in the orthography that Novelli (1985) employs throughout the grammar. ${ }^{10}$ However, as a consequence of this research in related languages, it has become common to assume that the low vowel in a [+ATR] environment is phonetically advanced, an assumption that will be tested by further research.

(9)
Harmonic
Vowels

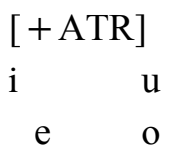

(a)

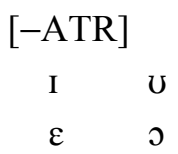

a

\section{Verbal Morphology}

The verbal complex has agglutinative morphology that abides by the observed universal governing affix order, proposed by Greenberg (1963: 93), in which the derivational morphology stands between the inflection and the root. This can be seen in the example in (10). The pronominal prefix [ $\left.\grave{\varepsilon}^{-}\right]$at the left edge and the passive voice present conditional voice marker for third person constitute the set of inflectional affixes in this form. The causative prefix [to-] and the frequentive affix [án-] respectively take the left and right positions proximal to the root and are derivational suffixes. Dative/applicative suffix [-akìn] is in an intermediate position between inflectional and derivational suffixes. In this example, great irregularity in [ATR] specifications is notable. The pronominal prefix and the frequentive and applicative suffixes have vowels that are specified for [-ATR]. Vowels in the causative prefix, the root and the TMA inflectional marker, as well as a secondary vowel in the applicative suffix, have a [+ATR] specification.

\footnotetext{
${ }^{10}$ In his description of the language, Novelli claimed this vowel to be a distinct phoneme, but opted in his descriptive grammar to follow the orthography of Westermann and Ward, employing a single letter to characterize advanced and non-advanced variants.
} 


\section{(10) INFL DER ROOT DER DER INFL}

$$
\begin{aligned}
& \grave{\varepsilon}-\text { to }- \text { doy - án - akín - jò } \\
& 3 p \text { CAUS 'pinch' - FREQ - DAT - PASS.PRS.3s/p } \\
& \text { 'They are caused to be frequently pinched for (the purpose of)' }
\end{aligned}
$$

The discontinuous pattern of [ATR] specifications can be explained by the existence of lexical levels that are distinguished by the application of separate sets of [ATR] harmony rules at different points in the construction of the word form. A description of the three-level model of word formation appears in $\$ 3.1$.

Nonetheless, simple rule applications by morpho-phonological level do not explain all of the discontinuities in [ATR] harmony domains dependent upon the language's morphology, and spreading processes cannot be summarized as simple applications of Autosegmental Theory (Goldsmith, 1976, 1990; Lieber, 1987). In (11), the verb [iki-dón-ar-ítàè] 'You have been pinched away,' also shown in (11a), has a TMA marker [-ítàè]. Following an autosegmental theoretical (AT) approach, the association lines in (11b) extend from the [-ATR] autosegment to the harmonytriggering root vowel [0] and to underspecified segments which surface as [a] under phonological rules corresponding to the first morpho-phonological level. From the [+ATR] autosegment, an association can be made only to the final [+ATR] vowel, as forming an association line between the vowel [í] and the autosegment would cross one connecting the [-ATR] and the recessive suffix vowel. One of the basic conventions of AT is the prohibition on the crossing of association lines. The vowel [í] would thus lack [ATR] feature specification, a contradiction of attested surface forms. The alternative to the crossing of association lines would have the underspecified suffix vowel associate to the [+ATR] autosegment. By the phonological rules corresponding to MP Level 1 for $[\mathrm{a} / \mathrm{o}]$ alternating suffixes, explained in $\S 4.1$ (18), this would result in the principal suffix vowel surfacing as [o] rather than $[\mathrm{a}]$. This is unattested in a verb with a $[-\mathrm{ATR}]$ root vowel.

a. iki-dón-ar-ítàè

$2 p$-pinch-IT-A.IND.PASS.PRS.PRF.2p

'You have been pinched (away)' 
b. $*[-\mathrm{ATR}][+\mathrm{ATR}]$<smiles>CCC1CC1</smiles>

-dón (I)tà è

c. $*[-\mathrm{ATR}][+\mathrm{ATR}]$

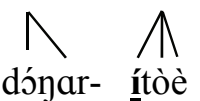

Arriving at an explanation for [ATR] harmony domains in the Karimojong verbal complex requires going beyond a simple AT spreading model. It must specify structure internal to the morpheme and describe the interface between morphological structure (hereafter M-structure) and phonological structure (P-structure), and its relationship to harmony processes. This explanation is effected in $\S 3.2$.

3.1 Three-Level Model. A lexical phonology framework, in which groups of morphemes can be affixed with the application of corresponding sets of phonological rules, provides a basis for explaining the data. A listing of selected Karimojong morphemes, with their levels of affixation and the [ATR] harmony processes that apply to them, is presented in Appendix A. Phonological rules corresponding to each morpho-phonological level are listed below in (12).

\section{(12) MP Level 1:}

Bidirectional root-controlled harmony

Suffix-controlled [-ATR] harmony

Consonant Voicing [+ATR] Adjacency Effect

[ATR] Dissimilation Rule before a-initial suffixes

Causative prefix voicing + spirantization rule

\section{MP Level 2:}

Suffix-controlled [+ATR] harmony

\section{MP Level 3:}

No [ATR] harmony processes 
Illustrations of the word formation procedure are shown in (13). The morphology is built step by step, each marked according to its corresponding constituent, which in turn undergoes the corresponding phonological processes. In (13), [غ̀-to-don-ánakín-jò]- 'they are caused to be frequently pinched for (the purpose of)', first presented in (10), shows Level 1 processes encompassed by the small rectangle. Inside, the morpheme string /tA $+\mathrm{don}+\mathrm{An}+\mathrm{Akin} /$, with the unspecified archiphoneme A filling the vowel slots of the derivational suffixes, undergoes a featurefilling bidirectional [-ATR] spread from the root vowel [-o-] of the root [-doy-] 'pinch'. The verbal complex then becomes /to-don-an-akìn/, as the archiphonemes receive the $[-\mathrm{ATR}]$ specification.

The Level 2 phonological process inside the larger rectangle consists of a [+ATR] harmonic spread leftward with the affixation of TMA marker [-jo]. The vowel of the TMA marker -jo spreads its [+ATR] feature to all vowels leftward, forming a second intermediate form /-to-doj-ạ́n-akkín-jò/. The [-ATR] vowels of the root and of the causative prefix receive a $[+\mathrm{ATR}]$ specification, changing them to $/ \mathrm{o} /$. The low vowels of the remaining suffixes are advanced in their phonetic realization [a]. Bracketed in boldface type are actual and potential L3 processes. The pronominal prefix /غे-/ 'they' undergoes no vowel harmony processes and retains its original ATR specification.

The diagram also shows the site in which the frequentive affix [-eenen] would be placed in a Level 3 process. Such a derivation is illustrated in example (14) and is discussed in the following section.

(13) Level 1: tA + doy + An + Akin $\rightarrow$ to doy an akìn

Level 2: todonanakìn + jo $\rightarrow$-to-don- án-akín-jò

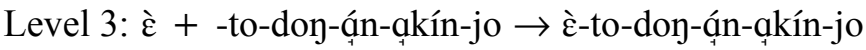

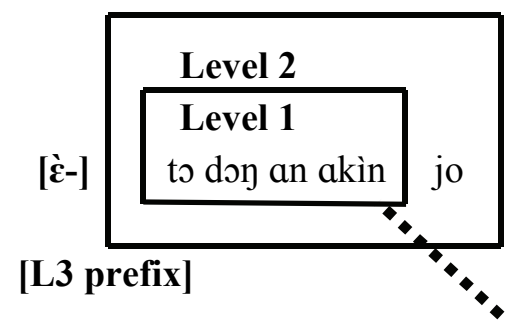

$\rightarrow$ غ̀-to-don-ạ́n-ạkín-joCL1.3p-CAUS-pinch-FREQ-APPL-PASS 'they are caused to be frequently pinched (for)'

\section{[L3 affix]}




\subsection{The Morphology-Phonology Interface and [ATR] Feature Spreading. A} discussion of linguistic structure in Karimojong with an explanation for the spreading of phonological features must at some point refer to a model of word formation in which morphology and phonology are interdependent. The model proposed here and illustrated in (14) is a variant of lexical phonology, based on Odden (1993), Booij (1988, 1992) and Booij and Rubach (1984) in which the morphosyntactic structure of a lexical entry is created simultaneously with the application of prosodification algorithms. The M-structure and P-structure are both then available for the application of phonological rules. M-structure includes the morpheme/phoneme string, a meaning, headmarking, and an encoding of the levels of application for the affixes and the phonological processes that accompany them. Each morpheme contains a phonological head, which is connected to a Prosodic Word (PW) node that can be part of a recursive PW word structure. In the verb root, the phonological head is the leftmost vowel. In each affix, it is the vowel closest to the root vowel. For suffixes, the phonological head is the leftmost vowel, while for prefixes it is the vowel furthest to the right. Feature spreading takes place through percolation from the privileged positions through this recursive structure, as seen in proposals by Hulst and Weijer (1995) and Hulst and Dresher (1998).

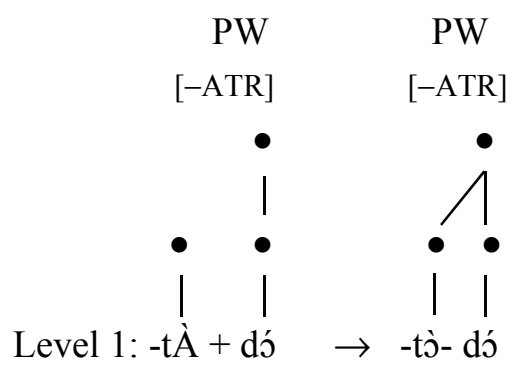




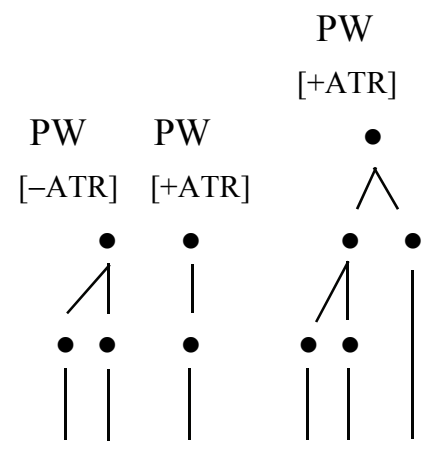

Level 2: -tòdó + -è $\rightarrow$-tòdó- è
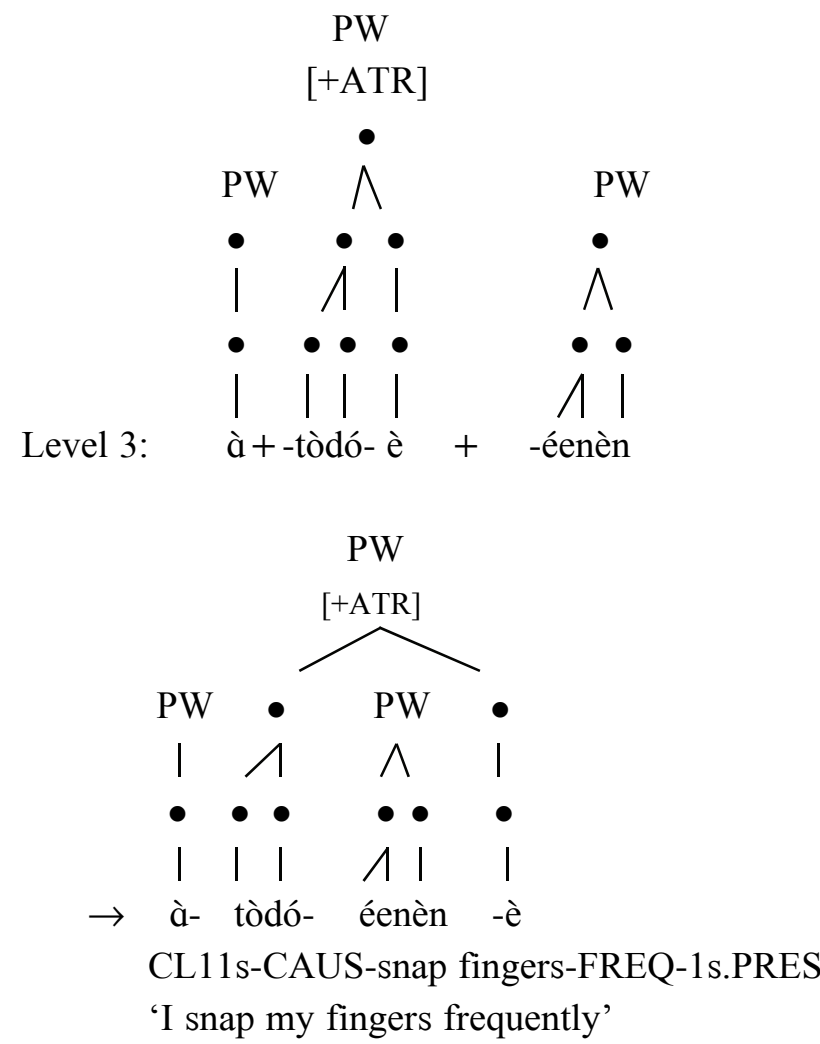

Level 1 affixes are proposed to be historically older forms, and are all recessive under exhaustive bi-directional root-controlled spreading of a [+ATR] or [-ATR] 
specification. Level 2 affixes are proposed to be more recent, but have been incorporated phonologically to the extent that they trigger a leftward-spreading [+ATR] suffix-controlled process. The pronominal prefix and the frequentive suffix shown in the examples are classified as Level 3 affixes based on their lack of participation in harmony processes. Level 3 morphology is proposed to consist of two types of affixes within the historical model: newer affixes in the process of being incorporated into the system of phonological rules, and older ones that have become inactive through phonological erosion and provide no evidence for classification as Level 1 or Level 2 morphology. In the following sections, the evidence in support of this model is reviewed through a study of the data illustrating the harmony rules on each level.

\section{Phonology of the First Morpho-Phonological Level}

The phonological processes of the first morpho-phonological level include bidirectional root-controlled [ \pm ATR] spreading, localized [-ATR] spreading domains generated by coarticulation effects, and [ATR] dissimilation in specific types of vowel sequences. As the latter two occur within the context of Level 1 morphological processes, rather than across the board without exception, they meet the definition of lexical, rather than post-lexical rules.

4.1 Bidirectional Root-Controlled Harmony. In examples (15a) through (15k) appear cases of root-controlled harmony. They are of infinitive forms representing the two [ATR] environments, with the root vowels presented in bold type and underlined. Examples (15a) through (15f) are [-ATR] verbs, while verbs in (15g) through $(15 \mathrm{k})$ are [+ATR]. Each root is preceded by the infinitive prefix [ákI-], in which [I] is an archiphoneme of the vowel that alternates according to the phonological environment. This vowel is interpreted as underlyingly unspecified for [ATR], and surfaces harmonically with the same specification as that of the root vowel. It is notable in the case of (15f) that the root vowel triggering [-ATR] spreading is $[\mathrm{a}]$, indicating that this vowel, far from being neutral as described in many [ATR] harmony systems, actually triggers harmony from a privileged position and patterns as a $[-\mathrm{ATR}]$ vowel. 
The causative prefix is affixed on Level 1 and undergoes root-controlled harmony. This prefix is selected according to the class of the verb to which it is affixed.
a. ákí-dón 'to pinch'
g. ákí-dón
'to castrate'
b. ákí-bớk 'to swing south'
h. ákí-fúk
'to smear'
c. ákí-nók 'to light fire'
i. ákí-nók
'to go near'
d. ákí-b $\underline{\varepsilon}$ 'to agree'
j. ákí-bélè̀
'to change
e. ákì-ír 'to test'
k. ákí-lík
'to swallow'
f. ákí-cáp 'to weed'

The vowel of the affix of Class 1 verbs is determined by the vowel of the verb root, while that of Class 2 verbs selects vowels $/ \mathrm{I} /$ or $/ \mathrm{i} /$ in agreement with the [ATR] specification of the root vowel. A phonological rule $t>z$ before $[i, I]$ makes the surface form of the causative prefix [-zi-] or [-zI-], according to the [ATR] specification of Class 2 verbs, or in the cases of Class 1 verbs with root vowels [i] or [I]. Rules applied to the causative prefix appear in (16), and examples of their application are shown in (17).

(16) Class 1 Verbs: $\mathrm{t}+$ root vowel

Class 2 Verbs: $\mathrm{t}+\mathrm{i}$

Phonological rule: $/ \mathrm{i} / \rightarrow \alpha[\mathrm{ATR}] / \mathrm{t} \_+\mathrm{C}(\mathrm{VC})_{0} \mathrm{~V}$

$\alpha[\mathrm{ATR}]$

Phonological Rule: $\mathrm{t} \rightarrow \mathrm{z} / \_\{\mathrm{i}, \mathrm{I}\}$

(17) $\underline{\text { Class }} \underline{\text { Infinitive }}$ Causative $\underline{\text { Gloss }}$

a. Class 1 ákí-cáp ákí-tá-cáp 'weed'

b. Class 1 ákí-dón ákí-tó-dón 'pinch'

c. Class 2 ákí-lìp ákí-Zi-lìp 'pray'

d. Class 2 ákì-dón ákì-zí-dón 'castrate'

Recessive derivational morphemes illustrate the extent of the bidirectional rootcontrolled domain. The most common type of derivational morpheme in Karimojong 
contains a 'characteristic vowel,' which surfaces as [a] when the root vowel has a [-ATR] specification, and as [o] when the root vowel specification is [+ATR]. Among these morphemes are the frequentive suffix [-Án], marked with a high tone, the itive [-Ar], and the applicative suffix [-Ákìn]. Examples with the root vowels bolded and underlined appear below. The [-ATR] verbs appear in (18), and the [+ATR] verbs are likewise presented in (19).

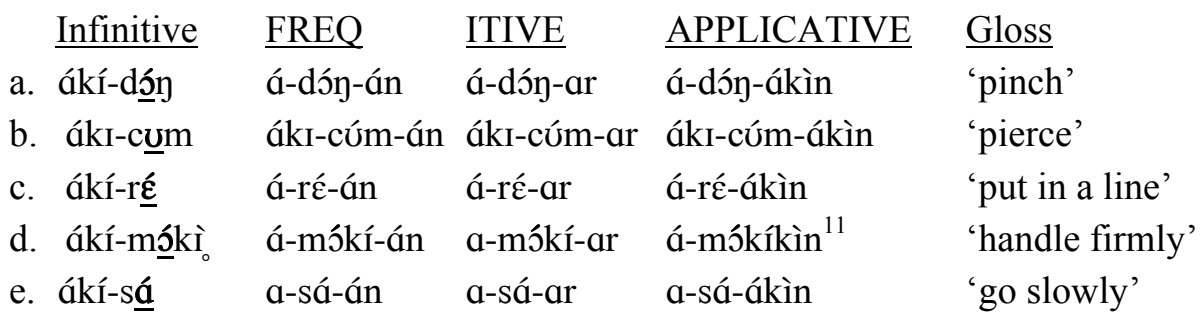

$\begin{array}{lllll}\underline{\text { Infinitive }} & \underline{\text { FREQ }} & \underline{\text { ITIVE }} & \underline{\text { APPLICATIVE }} & \text { Gloss } \\ \text { a. ákí-bú } & \text { ákí-bú-ón } & \text { ákí-bú-or } & \text { ákí-bu-(ó)kìn² } & \text { 'knock down' } \\ \text { b. ákì-tùle } & \text { ákì-tùle-ón } & \text { ákì-tùle-or } & \text { ákì-tùle-ókìn } & \text { 'blow on fire' } \\ \text { c. ákì-lík } & \text { ákì-lík-ón } & \text { ákì-lík-or } & \text { ákì-lík-ókìn } & \text { 'swallow' } \\ \text { d. ákí-fúk } & \text { á-fúk-ón } & \text { á-fúk-or } & \text { á-fúk-ókìn } & \text { 'smear' } \\ \text { e. ákí-nók } & \text { á-nók-ón } & \text { á-nók-òr } & \text { á-nók-ókìn } & \text { 'go near' }\end{array}$

Two other Level 1 suffixes that share the same underlying segmental values and are distinguished only by tone are the frequentive /-Ùn/ and the ventive /-Ún/. These suffixes show an incomplete assimilation into Level 1 phonological rules in that they receive [-ATR] spreading only when the verb root lacks a consonant coda, or when adjacent to the [-ATR] extension vowel following a process of intensive reduplication of a [-ATR] root. They otherwise surface with [+ATR] vowel specifications. Proposed phonetic and historical causes for this phenomenon are discussed in $\S 4.2$ and $\S 6.4$. Cases of this frequentive-ventive suffixation onto vowelfinal roots of [-ATR] verbs are shown in (20a) and (20b). In both cases the suffix vowel surfaces as $[\mho]$, the $[-\mathrm{ATR}]$ allomorph. This is to be contrasted with the cases of suffixation onto consonant-final [-ATR] roots in (20c) and (20d), in which the suffix vowels surface as $[\mathrm{u}]$. Cases of verbs with [+ATR] roots appear in (20e) and

\footnotetext{
${ }^{11}$ There is vowel elision in the applicative suffix of this form.
} 
(20f); the surface forms of their frequentive and itive suffixes have [+ATR] specifications. Examples of [ATR] feature spreading under intensive reduplication are shown in (20g), (21b) and (21d).. In all cases, the suffix is preceded by an extension vowel bearing the [ATR] specification of the root vowel, which in turn influences the specifications of the suffix vowels.

\begin{tabular}{|c|c|c|c|c|}
\hline & $\underline{I N F}$. & $\underline{\mathrm{VEN}}$ & $\underline{\text { FREQ+VENTIVE }}$ & $\underline{\text { Gloss }}$ \\
\hline a. & ákí-bú & á-bú-ùn & á-bu-únùn & 'return' \\
\hline$b$ & ákí-dó & á-dó-ùn & á-do-únùn & 'snap one's fingers' \\
\hline c. & ákí-dón & á-dón-ùn & á-dón-únùn & 'pinch' \\
\hline $\mathrm{d}$ & ákí-łók & áfókùn & á-fók-únùn & 'become good' \\
\hline e. & ákì-dó & a-dó-ún & a-dó-únùn & 'produce, deliver child' \\
\hline 酐 & ákì-túlé & ákì-túle-ún & ákì-túle-únùn & 'blow on fire' \\
\hline & $\begin{array}{l}\text { ákí-túp - } \\
\text { ákí-tùpứ }\end{array}$ & 'to follow' & & \\
\hline
\end{tabular}

The extent of the bidirectional root-controlled domain can be shown through examples of infinitive forms with derivational morphology. Cases of [-ATR] verbs appear in (21a) and (21b), while [+ATR] cases are illustrated in (21c) and (21d). In (21a), the [-ATR] feature of root vowel [0] spreads to select the [-ATR] variant of the $[\mathrm{a} / \mathrm{o}]$ alternating suffixes $[-\mathrm{A} n]$ and [-Akin], and leftward to provide [-ATR] values to the vowels of the infinitive and causative morphemes, which are underlined and bolded. In (21b) the [-ATR] feature spreads bi-directionally from root vowel $[\mho]$ of the root [com] - 'to pierce'- onto the vowel extensions used in and after the reduplication of the root and the vowel of the ventive suffix. In (21c) the [+ATR] feature of the root vowel [o] spreads bi-directionally to select the [+ATR] variant of the $[\mathrm{a} / \mathrm{o}]$ alternating suffixes, and provide [+ATR] vowels for the infinitive and causative prefixes. In (21d) the root vowel [i] likewise spreads its [+ATR] features bi-directionally. The initial [a] of the infinitive morphemes in these examples has not been analyzed instrumentally to determine the degree of advancement or retraction. 


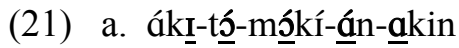

INF-CAUS-handle firmly-FREQ-APPL

'to cause to frequently handle firmly (for)'

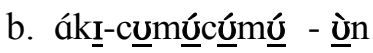

INF-pierce repeatedly-VEN

'to pierce repeatedly (this way)'

c. ákị- zị - dóny- oón - ókin

INF-CAUS-castrate-FREQ-APPL

'to cause to castrate (for)'

d. ákị- rimírímín-ùn

INF-go around repeatedly-VEN

'to go around repeatedly (this way)'

Two additional cases delineate the application of bidirectional root-controlled harmony. Recessive TMA markers and specific paradigms of narrative mood pronominal prefixes are classified as Level 1 affixes as they are shown to undergo this phonological process. In (22), narrative mood examples in the first person singular and two alternate forms of the third person plural are shown in the aorist past tense, which throughout the language tends to be coded by recessive, neutral or phonologically eroded suffixes. Examples (22a) through (22e) show the [-ATR] case, in which the root vowel $[\mho]$ triggers bi-directional spreading, including

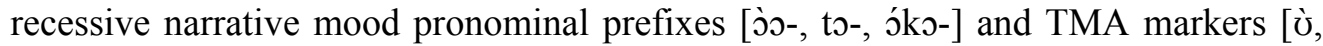
àta, a]. Examples (22f) through (22j) show the [+ATR] case with alternating pronominal prefixes [òo-, to-, óko-] and TMA markers consisting of [-o, -to, -o, -è]. Examples $(22 \mathrm{~g}),(22 \mathrm{~h})$ and $(22 \mathrm{j})$ shows the elision of the final voiceless vowel and substitution of the voiced vowels from the [+ATR] suffix. In example (22i), it can be deduced from the affix of the [-ATR] case in (22d) that the TMA marker is a voiceless vowel. Voiceless vowels are neutral or recessive in Karimojong, and this is one more indication that the harmony trigger for the alternation of the pronominal prefix is the root vowel and not the TMA marker. This is in addition to the fact that the active voice markers in (22b) through (22d) and (22g) through (17i) represent a 
category of [a/o] alternating TMA markers, as observed in Novelli (1985: 232-262) and Lesley-Neuman (2007: 45).
a. ákí-tớp
b. j̀-tưpứtứp-ù àè̀jy
c. to-tơpútós-àta íkèz
d. to-tơpứtóp-a íkèz
e. óko-tùpưtứp-ùì ${ }^{13}$ àęj̀
f. á-múrò
g. òo-mur-ò àę̀̀y
h. to-mur-oto íkèz
i. to-mur-o íkèz
j. óko-murò̀ àeò̀y

'to follow'

'....and I repeatedly followed'

'....and they repeatedly followed'

'... and they repeatedly followed ${ }^{12}$

'....and I was repeatedly followed'

'to sacrifice'

'...and I sacrificed'

'....and they sacrificed'

'....and they sacrificed ${ }^{14}$

'....and I was sacrificed'

While the alternation of the narrative/imperative mood pronominal prefixes as Level 1 morphemes is widespread, there are exceptional cases in which they behave as most pronominal prefixes do - as neutral Level 3 affixes. Examples in (23) show the case of the [+ATR] verb [ákí-ruc] 'to tie'. The infinitive form is shown in (18a). The root vowel spreads its [+ATR] specification to the vowel of the alternating infinitive prefix; both vowels are underlined and bolded to indicate the extent of the [+ATR] feature spread. In (18b) through (18e) the [+ATR] feature spreads only to the suffixes, as the narrative mood prefixes subject to Level 3 phonology do not alternate.
a. ákí-rüc
'to tie'

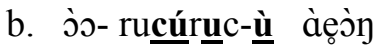
'....and I repeatedly tied'
c. to- rúcúrucuc-ôto íkèz
'and they repeatedly tied'
d. to- rúcúruc-o íkèz
'....and they repeatedly tied ${ }^{, 15}$
e. óko- rücúrúc-ùì àeò̀y
'...and I was repeatedly tied'

\footnotetext{
${ }^{12}$ This is an alternate form for the third person plural.

${ }^{13}$ There is some irregularity in Novelli's transcriptions. At times this final vowel is represented as [i], at other times as [I].

${ }^{14}$ This is an alternate form for the third person plural.

15 This is an alternate form for the third person plural.
} 
Irregularities in vowel harmony domains can be produced by local interactions. These interactions may be due to co-articulation and adaptations by the phonological grammar to preserve distinctiveness in coding. As they co-occur with Level 1 affixation process, these adjacency effects will be explained in the following section.

4.2 Adjacency Effects. There are two kinds of adjacency effects intervening in [ATR] harmony domains in Karimojong. The first consists of consonant-generated features, in which the gesture of producing the consonant contiguous to a vowel initiates a disharmonic domain. The second is a vowel dissimilation rule that preserves distinctiveness within a vowel sequence.

One reviewer questioned the inclusion of discussions regarding phonetics. They are deemed necessary to explain surface [ATR] patterns of the verbal complex, and to provide insights for future research in the phonetics and phonology within grammaticalization processes. Two types of consonant-generated co-articulatory effects are proposed here for Karimojong. The first is a [+ATR] feature generated by tongue root advancement for the expansion of the pharyngeal cavity, a strategy to promote the continuation of voicing for a stem-final consonant ${ }^{16}$, or for articulating nasality. In the case of the former, the expansion of the supralaryngeal cavity creates a pressure gradient that allows for the continuation of vocal fold vibration (Bell-Berti 1975; Westbury, 1979, 1983; Westbury and Keating, 1986). Likewise, Bell-Berti $(1973,1980)$ identified the expansion of the pharyngeal cavity common strategy in nasal articulation. The proposal here is that these constitute co-articulation strategies that are 'cognitive and acquired' (Bermudez-Otero, 2007: 499; Keating, 1988c: 287288; Pierrehumbert, et al 2000: 285-286). As proposed by Trigo (1991), when consonants affect contiguous vowels in this manner, they should be considered phonologically [+ATR]. Three examples are shown in (24).

In example (24a), the [-ATR] verb [ákí-dón] - 'pinch' appears in a derived form that includes the frequentive with the ventive, each carrying [+ATR] high back vowels. Nonetheless, in the reduplicated form, to which the [-ATR] stem-enlarging vowel [0] is affixed, the alternating suffix adopts a [-ATR] specification, changing the ventive suffix vowel to [v]. This pattern is repeated in (24b) and (24c) with the stem-enlarging vowel [v]. Stem-enlarging vowels owe their specifications to root vowels, and override co-articulatory effects from adjacent consonants.

\footnotetext{
${ }^{16}$ As far as can be determined, this occurs only at a morpheme boundary.
} 


\begin{tabular}{|c|c|c|c|}
\hline$\underline{\text { Infi }}$ & $\underline{\text { FREQ }+ \text { VEN }}$ & Reduplication + VEN & Gloss \\
\hline $\bar{a}$ & $\overline{a ́ \text { dón-ún-ùn }}$ & 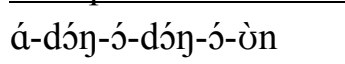 & pinc \\
\hline ák & ákí-sứb-ún-ùn & ákí-sưb-Ú-sứb-Ú-ùn & \\
\hline '́lb̀̀ & ákì-cơm-ún-ùn & ákì-cơm-ư-cóm-Ú-ùn & 'pierce \\
\hline
\end{tabular}

It could be proposed that in Karimojong the alveolar nasal in itself provides the [+ATR] feature affecting the vowel, which is overridden by root-controlled processes in the absence consonant codas. A contrast of the forms in (25a), in which the [-ATR] verb appears in the ventive, to $(25 \mathrm{~b})$, where the elision of the final alveolar nasal changes the status of the preceding vowel to [-ATR], supports this assertion. The forms in (25d) and (25e) serve as contrasts in that they show the [+ATR] status of the suffix for [+ATR] adjectival verbs. In other languages of the Teso-Turkana cluster, the elision of nasal codas in equivalent suffixes accompanies the weakening of their vowels through de-voicing. Examples (57a) and (57c) in $\S 6.4$ show this phenomenon in Turkana; the suffix receives its [-ATR] feature from the root vowel. Example (57b) provides proof that the [ATR] specification of the suffix vowel is not linked to the alveolar nasal coda in Turkana in that the ventive suffix vowel has a [-ATR] specification where the coda is retained. Loss of the nasal coda in (57d) accompanies de-voicing of the vowel, which receives its [+ATR] specification from the root. Examples from Toposa in (63) show nasal elision accompanying the devoicing of the suffix vowels, but having no impact on their [ATR] specifications.

These facts and other evidence from Karimojong point to an additional explanation. In example (25c), there are [+ATR] vowel specifications in the ventive and frequentive suffixes on a [-ATR] verb, which ends in a voiceless consonant coda that elsewhere does not serve as a harmony blocker. A proposal by Novelli (1985: $213)$, further developed in $\S 6.4$, is that frequentive suffixes in Karimojong pass through several evolutionary stages, in which phonologically inactive reduplicated forms with [+ATR] vowels gradually break up into two separate suffixes, one frequentive and the other directional, and gradually incorporate phonologically into the verbal complex, later adopting [ATR] harmony rules. It is proposed that [-únùn] is undergoing this process. Its recessive behavior in the absence of consonant codas and its neutrality elsewhere show an affix in transition, with the co-articulatory effects as factors shaping its behavior. Essentially, the [Ún] frequentive and [Ùn] 
ventive in Karimojong are not as fully integrated into the phonological system as they are in Turkana and Toposa.
a. ádáùn 'to finish'
b. àdàứ '17 'he finished', 'it is enough'
c. áfókúnùn 'become good, this way'
d. árónúnùn 'become bad, this way'
e. álílímúnùn 'become cold, this way'

The second co-articulatory effect impacting adjacent vowels involves the retraction of the tongue for the pronunciation of $[\mathrm{r}]$, a fact that has been verified cross-linguistically for both rhotics in general and for this particular trill (Harris, 2006; Recasens \& Espinosa, 2002; Recasens, personal communication). The retraction of the tongue generates a [-ATR] feature, which changes an expected [o] of the itive suffix or the itive with the frequentive to [0], and, when unimpeded by other co-articulatory effects, generates a localized bidirectional [-ATR] spreading domain of approximately two syllables from the head vowel preceding the trill. A grounded explanation for this phenomenon is the phonologization of this $\mathrm{V}+[\mathrm{r}]$ coarticulation effect by the speech community, but limited in Karimojong to the vowel in the morpheme and the spreading domain. It is also simultaneous with a diachronic vowel merging process in which languages are proposed by some authors to have evolved from a ten-vowel to a nine-vowel harmony system, a situation common to a number of Eastern Nilotic languages (Vossen, 1982; Dimmendaal, 1983, 2002; Heine 1980; Hall \& Creider, 1998). According to Dimmendaal (2002), the diachronic development of this type of harmony appears to have occurred in a two-step process. The [+ATR] low vowel [a] first merged with [0], and the [-ATR] feature of the sound generated a reinterpretation by the speech community and resulted in the localized spreading domain. The table in example (26) allows for the comparison of forms by showing the itive, frequentive plus itive, applicative, and frequentive plus applicative verb forms. Only those forms with the itive, containing [r], show [-ATR] spreading. This highlights the rhotic as the trigger.

\footnotetext{
${ }^{17}$ The laxing and de-voicing of the vowel in the absence of the alveolar nasal is an alternation very common in Turkana, as noted by Dimmendaal (1983).
} 
(26) Itive, Frequentive, Applicative Combined Forms

\begin{tabular}{|l|l|l|l|l|}
\hline Meaning & 'castrate' & 'produce child' & 'sacrifice' & 'fall' \\
\hline Infinitive & ákì-dón & ákì-do & á-murò & á-dòre \\
\hline Itive (IT) & ákI-dóy-òr & ákì-dó-òr & á-muró-òr & á-dó-òr \\
\hline FREQ + IT & ákI-dóy-on-òr & ákì-do-ón-òr & á-muró-ón-òr & á-dó-ón-òr \\
\hline APPL & ákì-dóy-ókìn & ákì-dó-(ó)kìn & á-múr-ókìn & ádo-ókìn \\
\hline FREQ+APPL & ákì-dóy-ón-ókìn & ákì-do-ón-ókìn & á-múró-ón-ókìn & ádo-ón-ókìn \\
\hline
\end{tabular}

As the spreading of this [-ATR] feature is bi-directional, it causes the selection of the [-ATR] variant of TMA morphemes, in those conjugations where the TMA marker is recessive. This occurs whether or not the root vowel has been included in the $[-\mathrm{ATR}]$ spreading domain, which is not exhaustive. This fact provides evidence for the $[-\mathrm{ATR}]$ feature being phonologically active in Level 1 processes, rather than representing merely a default value. Evidence provided by Level 1 processes in Karimojong sustain Variable [ATR] Dominance theories of [ATR] feature spreading (Casali, 2003), which allow for [-ATR] or [+ATR] features to be dominant in spreading domains. Variable Dominance theories appear in opposition to Universal [+ATR] Dominance theories, which sustain that the [+ATR] feature is universally dominant. The dominance of [+ATR] domains characterizes only Level 2 processes in the language. It is the thesis of this paper that [ATR] feature dominance in Karimojong varies with the morpho-phonological level on which phonological rules are applied.

In example (27), verbs originally with [+ATR] roots select [-ATR] recessive TMA markers in Form B conjugations in the continuous aspect present/future and past. The stem-enlarging vowels, the specification of which depends upon that of the stem vowel, in this instance, by their transformation under the localized domain, determine the selection of the $[-\mathrm{ATR}]$ inflectional marker.

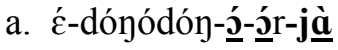
'...I (will) repeatedly castrate.'

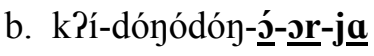
'...that he repeatedly castrate(s)/
will repeatedly castrate'

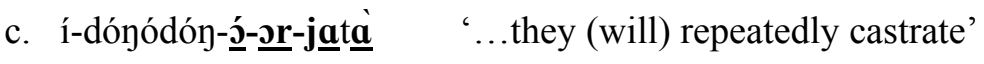


The second type of adjacency effect involves dissimilation, an alternation in vowel quality that aids in perception by the speaker. When [-ATR] vowels $[\mathrm{I}, \varepsilon, 0, v]$ occur in stem-final position before suffixes beginning with $[\mathrm{a}]$, followed by consonants that are $[+$ cor $]$, their [ATR] values change to those of the corresponding tense vowels $[i, e, o, u] .{ }^{18}$ This process is shown in (28). In (28a), the vowel $[\varepsilon]$ of the infinitive [ákí-ré] 'put in a line' becomes [e], upon suffixation of the itive or the frequentive with itive, both of which begin with [a]. In (28b), vowel [0] of the infinitive [ákí-dó] 'to snap one's fingers,' likewise becomes [o]. In (28c), vowel [v] of the infinitive [ákí-bó] 'to return' becomes [u] under the same suffixation condition. Example (28d) shows the tensing of the voiceless vowel [I] $]$ and its reversion to modal status under affixation. The data also show the root vowel [0] tensing and becoming [o] in affixed forms in this example.

\begin{tabular}{|c|c|c|c|}
\hline Infinitive & $\underline{\text { Itive }}$ & $\underline{\text { FREQ + IT }}$ & $\underline{\text { Gloss }}$ \\
\hline a. ákí-r乩 & 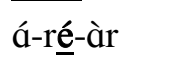 & á-rééćn-àr & 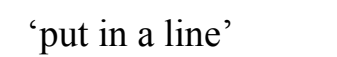 \\
\hline b. ákí-dó & á-dó-còr & á-dóo-án-àr & 'snap one's fingers' \\
\hline c. ákí-bú & á-búu-àr & á-búú-án-àr & 'return’ \\
\hline d. ákí-mokì & á-mokí-àr & á-mokí-án-àr & ‘agree' \\
\hline
\end{tabular}

This dissimilation process also occurs in stem-enlarging vowels under reduplication, shown in (29). Example (29a) shows the case in which the stemenlarging vowel [0] alternates to its [+ATR] counterpart [o], which appears underlined and in bold type. In the case of (29b), the alternation extends not only to the epenthetic vowel [0], but as well to the preceding root-final vowel with the same set of feature values.

a. áki-to-dónódónón-àr b.

INF-CAUS-pinch repeatedly-IT

to pinch (away) repeatedly á-dóódóó-àr

INF-snap one's fingers-IT

'to snap one's fingers (away)'

Bidirectional root controlled [ \pm ATR] harmony as the phonological component of the Level 1 affixation processes has been presented, with cases of localized disharmonic domains due to the phonologization of co-articulatory effects and

\footnotetext{
${ }^{18}$ This process appears not to apply when the [-an] suffix is followed by the dative [-ákìn].
} 
cognitive dissimilation. ${ }^{19}$ A complete account of Karimojong vowel harmony and of the distinction of morpho-phonological levels requires a discussion of [+ATR] suffixcontrolled harmony, a process confined to the second morphological level. This is carried out in the following section.

\section{Phonology of the Second Morpho-Phonological Level}

The phonological process that defines the second morpho-phonological level is [+ATR] suffix-controlled harmony. The affixation of a [+ATR] suffix that is a harmony trigger changes the [ATR] specification of most of the [-ATR] vowels to its left. Example (30) shows four cases of [+ATR] TMA marker suffixation on the [-ATR] Class 1 verb [ákì-to-jók] 'to cause to be good'. In (30a), the affixation of TMA suffix [-i] marking the indicative mood, active voice, Form A past progressive form, changes the [-ATR] specification of the vowel [0] to [+ATR], giving it the value [o]. Similar changes occur with other affix triggers in the remaining examples: affix [-ete] in (30b), [-jo] in (30c) and [-etei] in (30d). From the changes in the [ATR] specifications of both the root vowels and the vowels in the causative prefixes, which received their [ATR] specification from them, it can be deduced that [+ATR] suffix-controlled harmony is dominant over bidirectional root controlled harmony.

19 One reviewer has asserted that spirantization, phonologized co-articulation and dissimilation processes should be considered post-lexical. As they refer to the internal structure of the word, occur within word boundaries, and do not operate below native speaker awareness argue for their status as lexical rules. 
(30) Infinitive: ákì-tó́-Jók - 'to cause to be good 20

a. غ̀̀-tò̀-fók-1́

1s-CAUS-be good- IND.ACT.PST.PROG.A.1s

'I was causing to be good.'

b. ì-tò-fók-etè

2p-CAUS-be good- IND.ACT.PST.PROG.A.2p

'You were causing to be good.'

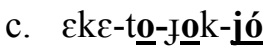

1s-CAUS-be good-IND.PASS.PST.PROG.A.1s

'I was being caused to be good."'

d. $\varepsilon k \varepsilon$-tó-łok-etei

1s-CAUS-be good- NARR.PASS.PST.PROG.A.1s

'...and I was being caused to be good.

The [+ATR] suffix-controlled harmony process is dominant over all Level 1 spreading processes, including the [-ATR] consonant-generated domain. This can be seen in (31). In (31a,), TAM marker [i] of the continuous aspect, present/future tense, first person, indicative mood spreads the [+ATR] feature to the stem-enlarging vowel and the vowel of the itive suffix, which have the value [0] before suffixation. In (31b), the TMA marker corresponds to continuous aspect, second person. In (31c), the TMA marker [-ete] for continuous aspect, past tense, indicative mood, third person plural likewise spreads its [+ATR] specification. The pronominal prefixes, as Level 3 affixes, are unaffected by this harmony process carried out in conjunction with Level 2 affixation.

${ }^{20}$ [عjok] -'be good' is a Class 1 verb. With the addition of the causative morpheme [to], the verb changes to Class 2. 
(31) Infinitive: -dóyódón-ó-or -repeatedly castrate (this way)
a. É-dóyódón-ó-or-
'I (will) repeatedly castrate'
b. ì-donodon-o-or-므 -
'You (s.) are/were repeatedly castrating.'
c. $\varepsilon$-doyodon-o-or-ete -
'They are/were repeatedly castrating.'

Nonetheless, [+ATR] spreading on the second morphological level can produce different outcomes from the assignment of [+ATR] specification to the archiphonemes under Level 1 processes. On Level 1, the feature-filling process assigns the characteristic vowel of $[a / o]$ suffixes the value $[a]$ in [-ATR] domains and [o] in [+ATR] domains. For the [+ATR] domain on Level 2, in which a featurechanging operation occurs, the $[\mathrm{a}]$ in an $[\mathrm{a} / \mathrm{o}]$ suffix does not convert into [o]. It remains phonemically [a], as shown by the comparison of the paradigms in example (32) below. Recent work on other African and European languages using ultrasound imaging techniques (Archangeli 2003; Gick, Pulleyblank, Campbell and Mutaka 2006; Benus and Gafos 2007) show the phonetic advancement of neutral vowels in [+ATR] environments in vowel harmony languages. In light of these findings, researchers have begun to indicate phonetic advancement of vowels heretofore considered to be neutral. This practice is also adopted here, given the physical difficulty involved in retracting the tongue within a [+ATR] environment in what fieldworkers attest to be a rapidly spoken, agglutinating CV language. It is also validated by articulatory and acoustic studies carried out with Maa, a historically related Eastern Nilotic language, by Guion, Post and Payne (2004). Work on this issue in Karimojong shall be the topic of future research.

In the paradigm corresponding to (32a) it can be noted that the uninflected infinitive is a [-ATR] verb with root vowel [0]. This selects the [-ATR] variants of the derivational morphemes [-Án, -Ar]. The paradigm shows pronominal prefixes with differing [ATR] specifications. Being Level 3 affixes, they are unaffected by harmony processes occurring on Levels 1 or 2 . This paradigm shows inflectional morphology for the continuous aspect, present/future tense. For singular forms and the first person plural, this is the low-toned suffix [-i]. For the second and third person plural, they are [-étè, -etè] respectively. There is an alternate form in the third person singular taking the passive voice inflection [-jò]. In all cases, the vowels in these inflectional morphemes carry [+ATR] specifications. In all cases, the root 
vowels have changed $[0] \rightarrow[\mathrm{o}]$. In the paradigm in (32b), the Class 2 pronominal prefixes are likewise unaffected by any harmony processes. All of the other vowels, however, possess [+ATR] specifications and all have the phonetic value [o], as befitting the Level 1 feature filling process under [+ATR] bidirectional root control. The Level 2 [+ATR] harmony process leaves them unaffected, as they already possess [+ATR] specifications.

Continuous Aspect Present/Future Tense

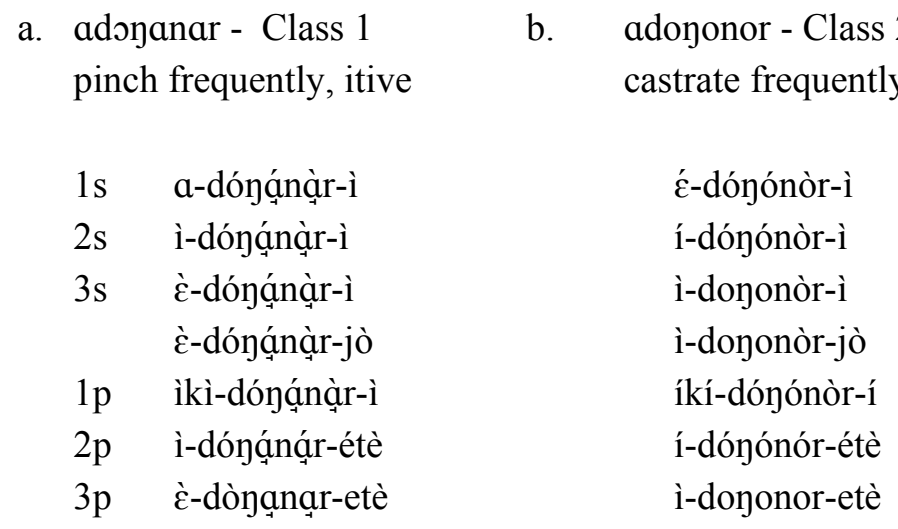

Therefore, one evident argument for distinguishing the first two morphophonological levels in Karimojong is the behavior of the vowel [a] under the harmony processes corresponding to each level. To reach the attested surface form in the [-ATR] case, it is necessary to posit separate levels with two distinct vowel harmony processes, the feature-filling bidirectional root control which provides the feature profile for $[a]$, then the feature-changing $[+\mathrm{ATR}]$ process that would phonetically advance it while changing the root vowel to a [+ATR] value. It differs from the [+ATR] case in that the characteristic vowel assigned on Level 1 is [o], which remains unchanged.

The word formation process illustrating this contrast, which includes a Level 3 process of affixing a neutral pronominal prefix, is shown for the [-ATR] in (33) and the [+ATR] case in (34). On the first level, the derivational suffixes are affixed to the root, and the complex undergoes bidirectional root-controlled harmony. On Level 2, the TMA marker is affixed, and a process of [+ATR] harmony is triggered. On Level 
3 , the affixation of the neutral pronominal prefix takes place. In this instance, the pronominal prefix is for the second person plural, which is the same for both verb classes, and there are two derivational morphemes with their respective characteristic vowels affixed to the verb. The [+ATR] TMA marker being affixed is [-étè], which codes the continuous aspect present/future tense for second and third person plural.

(33) ì-dón-ạ́n-ạ́kín-étè-'You (p.) are frequently pinched (for the purpose of..)’

$\begin{array}{llll}\text { Level } 1 & \text { dóy }+ \text {-AnAkin } & \rightarrow & \text { doyánákín } \\ \text { Level } 2 & \text {-dónáákín }+ \text {-étè } & \rightarrow & \text {-dóyánákínétè } \\ \text { Level } 3 & \text { ì-+-dónạnạkinétè } & \rightarrow & \text { ìdonạạkinétè }^{21}\end{array}$

(34) ídón-ón-ókín-jétè- 'He is being castrated (for the purpose of...)'

Level 1 don- +-AnAkin $\rightarrow$ dóyónókín

Level 2 -dóyónókín + -étè $\rightarrow$-dóyónókínétè

Level 3 í- +-dónónókínétè $\rightarrow$ ídónónókínétè

Examples drawn from contextual usage appear in (35) and (36). The [-ATR] derivational extensions bring new meanings to verbs, and have been made part of entire dictionary entries (Logiro and Ilukori, 2007).

a. ákí-gjél- 'to barter; á-gjél-ánàr- 'to sell (freq.)' / 'to cost'

ع-gjélạ́nạ́r-jò

$3 p$-sell frequently-PASS

'They cost.'

b. ákí -ziákín/ -sjákín- 'to begin'

ì-ziạ́kín-jò $\quad$ ctic

3s-begin-ACT.FUT.3s $\mathrm{s}^{22}$ work

'He shall now begin to work.'

${ }^{21}$ Novelli (1985) reports [a] as [a]. This does not change the evidence for distinct levels, as the vowels [a], [a] or [a] distinguished from [o] make the case.

${ }^{22}$ This is the alternate conjugation in the third person singular, not the passive. 

a. á-límókìn - 'to tell' ìkì-limokin-etè íčz $2 \mathrm{p}$-tell-FUT $\quad 2 \mathrm{p} \quad 1 \mathrm{p}$
'You will tell us.'

b. á-gólókin - 'to close'

$$
\begin{aligned}
& \text { ìnéz alopé á-gólókin-ì Ékèk } \\
& \text { 3s f.s-REFL 3s-close-3s.PST door } \\
& \text { 'She herself closed the door.' }
\end{aligned}
$$

\section{Inert Affixes and the Third Morpho-Phonological Level}

Affixes are defined as neutral when they contain vowels of the harmony set without participating in harmony. These include most pronominal prefixes, neutral TMA markers, and the reduplicated frequentive suffixes [-eenen] and [-itit]. Cases of affixes showing neutrality or activity only in certain environments are also discussed in this section.

6.1 Pronominal Prefixes. As implied by the pronominal forms seen in (30) through (32), the great majority of the pronominal prefixes are neutral and non-alternating, with the exception of a subset of narrative mood forms shown in example (22). Instances of pronominal prefix neutrality are particularly apparent when the [ATR] specification of the prefix differs from that of the particular harmony domain being exhaustively applied, and examples of these appear in bold type in (37). In (37a) through (37d), the first person singular and third person plural Class 2 passive voice pronominal prefixes remain neutral and non-alternating as the [-ATR] verb [ákIákì ] 'send', spreads its specification from the root vowel to the recessive TMA marker in examples (37a) and (37c), and the [+ATR] TMA markers spread their specification leftward in examples (37b) and (37d). In examples (37e) through (37h), the first person singular and third person plural Class 1 active voice indicative mood pronominal prefixes, which are specified for [-ATR], remain so under -ATR spreading in examples (37e) and (37g), but are also neutral as TMA markers [-i] and [-jetè] respectively initiate leftward [+ATR] spreading. 
(37) Infinitive: áki-áki - 'to send' (Class 2)
a. $\underline{\text { kkz-akI-tàè }}$ áę̀̀y
1s-send PASS.IND.PRS PRF 1s
'I have been sent'

b. $\underline{\mathbf{c k} \boldsymbol{\varepsilon}}$-aki-tetèì áęòn 1s -send-PASS.NAR.PRS PRF 1s '....and I have been sent'
c. ì-aki-tàè íkèz $3 p$-send PASS.IND.PRS PRF $3 p$

'They have been sent'

d. İ-akí-tó íkèz $3 p$-send-PASS-NAR.PRS PRF $3 p$ '... and they have been sent'

Infinitive: ákí-bíl - ‘to break' (Class 1)

e. à- bílíbíl -à 1s-send repeatedly-ACT.REFL.FUT 'I will send myself repeatedly'

f. à̀-bílíbìl-ì

1s-send repeatedly-ACT.IND.FUT

'I will send repeatedly'

g. ̀̀- bílíbíl-azì $3 p$-send repeatedly-ACT.REFL.FUT 'They sent themselves repeatedly' 
h. غ̀-bìlibil-i-etè

3 p-send repeatedly-ACT.IND.FUT

'They will send repeatedly'

An essential thesis of this evolutionary model is that affixes transition from one morpho-phonological level to another with the passage of time. The exceptional cases of pronominal prefix alternation is one such example of an affix in the initial stages of phonological integration, in that narrative mood forms undergo harmony processes on Levels 1 and 2 but are neutral in other moods. These active forms can be seen in the narrative mood paradigms with root-controlled and suffix-controlled harmony processes with a [-ATR] verb [akI-don]- 'to pinch'. In example (38), dominant [+ATR] harmony is triggered by the past continuous aspect marker [-etèi] and by the past perfect continuous aspect marker [-tetèi], as seen by the [+ATR] specification of the root vowel. As well, the pronominal prefixes in this paradigm[óko-], [íto-] and [to-] — are likewise specified as [+ATR]. In contrast, the paradigm of the aorist past, which tends to have neutral and phonologically eroded TMA markers, does not alter the [ATR] value of the root vowel, and the pronominal prefixes bear a $[-\mathrm{ATR}]$ specification.

Verb: akı-don

Form A, Narrative Mood, Passive Voice

a. Continuous Aspect Past b. Continuous Aspect Past Perfect c. Aorist Past

\begin{tabular}{|c|c|c|}
\hline óko-don-etèì & óko-doy-tetèì & óko-doy-ì \\
\hline íto-doy-etèì & íto-doy-tetèì & íto-doy-ì \\
\hline to-doy-etèì & to-doy-tetèì & to-doy-àè \\
\hline íto-doy-etèì & íto-don-tetèì & íto-doy-ì \\
\hline íto-doy-etèì & ito-don-tetèì & íto-doy-ì \\
\hline to-doy-etèì & to-doy-tetèì & to-don-àè \\
\hline
\end{tabular}

Additional examples can be seen in context. The [-ATR] verb [akí-ré], translated alternatively as 'to overpower' and 'to put in rows' is shown in (39a) in the indicative mood, passive voice, present/future tense with an inert pronominal prefix [aka-], 
which unlike the root vowel maintains its negative [ATR] specification under dominant [+ATR] spreading from TMA marker [-ó]. Examples (39b) and (39c) are cases in which the TMA markers are inactive and the pronominal prefixes retain [-ATR] feature specifications that originally spread from the root vowel under Level 1 processes. Example (39d) shows the pronominal prefix assuming the [+ATR] specification of the dominant TMA marker, which likewise changes the specification of the root vowel. This contrasts with the [ATR] specifications in $(39 \mathrm{c})$.

(39) akí-ré - 'to overpower' / 'put in rows'

a. ạkạ-ré-ó áeón

PASS.1s-overpower-PASS.IND.PRS/FUT 1s

'I am/will be overpowered'

b. ว̀ว-rغ̀

áeón

1s-overpower.NARR.PST 1s

'...and I overpowered.'

c. óko-rغ̀-ì áeóny

NARR.PASS.1s-overpower-PASS.PST 1s

'...and I was overpowered.'

d. óko-re-tetè̀

1s-overpower-PASS.NAR.PSTPRF 1s

'....and I had been overpowered'

6.2 Frequentive Affixes. The first of the two inactive frequentive affixes is [-eenen]. The examples in (40) demonstrate its neutrality. In examples (40a) through (40c), it maintains its [+ATR] specification and is unaffected by root-controlled [-ATR] spreading. Example (40a) shows that TMA marker [-tàè] receiving its [-ATR] specification from the root despite the intercalation of the frequentive suffix, the vowels of which are [+ATR]. That the harmony domain is bidirectional is seen in the [-ATR] specification of the causative prefix [-to-]. Example (40b) shows the 
case of the infinitival frequentive form, in which this suffix is likewise unaffected. Example (40c) shows another case of the [-ATR] root-controlled specification

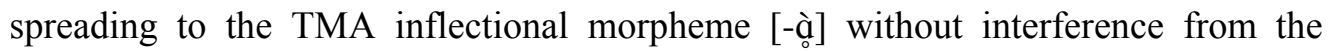
frequentive suffix specified as [+ATR]. Likewise, [+ATR] spreading processes show no effect on [-eenen], which carries a [+ATR] specification. Examples (40d) through (40f) show [+ATR] feature-filling spreading processes analogous to those in (40a) through (40c). The [-eenen-] suffix is unaffected by spreading from either of the two privileged positions in the verb forms under consideration, and in verb forms throughout the language.

\begin{tabular}{|c|c|c|}
\hline$\underline{\mathrm{INF}}$ & $\underline{\text { FREQ }}$ & $\underline{\text { Gloss }}$ \\
\hline a. ákí-dón & $\varepsilon$-to-dón-éenéne-tàè & 'He has frequently caused to pinch.' \\
\hline b. ákì-bú & á-bú-éenén & 'to return frequently' \\
\hline c. ákí-ré & à-rè-éenén-à & 'They frequently overpowered.' \\
\hline d. ákì-dón & ì-dóy-éenén-é-tòè & 'He has frequently castrated.' \\
\hline e. ákì-bú & ákì-bù-éenén & 'to knock down frequently' \\
\hline ákì-tùle & غ̀-tùlè-éenén-ò & 'They frequently blew on fire.' \\
\hline
\end{tabular}

The neutral TMA marker [-itit] as a special case of a neutral frequentive suffix appears to have arisen from the reduplication of the [-it] suffix. According to Novelli (1985: 214-215), it appears in a restricted number of verbs. It is equivalent in meaning to [-eenen], and may occur in isolation or with other TMA markers attached accompanied by processes of vowel elision. Its meaning is roughly equivalent to 'used to (do)' when it occurs as a synthetic morpheme incorporating inflections of the present or past perfect tenses. The phonological neutrality of this reduplicated form is shown examples (41a) through (41c), in which the [-ATR] verb roots go unchanged. However, the affixation of additional dominant [+ATR] TMA markers in examples (41c) through (41f) show the alternation of the root vowels and the narrative mood pronominal prefixes, changing their status to [+ATR]. It can be deduced through comparison that the alternations are triggered by the TMA markers, and not the neutral [-itit] suffix. 
(41) a. ì-don-itit ijòn

2s-pinch-ACT.FREQ.PST PRF 2s

'You used to frequently pinch'

b. k?ì- doy-itit íjòn

SUBJ.2s-pinch-ACT.FREQ.PST PRF $2 \mathrm{~s}$

'that you used to frequently pinch'

c. غ̀-tija-ítít

1s-do-FREQ.IMPF.

'I used to do'

d. òo-don-itit-e àè̀̀y

NAR.1s-pinch-ACT.FUT 1s

'....and I will frequently pinch'

e. k?ì-don-itit-o í̀̀z

SUBJ.2p-pinch-ACT.FREQ.PST PRF $2 p$

'that you had frequently pinched'

f. oo-don-itit-o

1́wòn

NAR.1p.-pinch-ACT.IND.PST PRF-1 1p.incl

'....and we had frequently pinched'

6.3 Neutral TMA Markers. The TMA marker [-it] stands alone as a phonologically neutral inflection for the present and past perfect tenses only in the singular number and in the first person plural. Paradigms for the [-ATR] verb [ákI-dón] 'to pinch' in the indicative and subjunctive moods are presented in (42). 


$$
\begin{aligned}
& \text { ákí-dón - 'to pinch' } \\
& \text { Active Voice, Present Perfect Tense }
\end{aligned}
$$

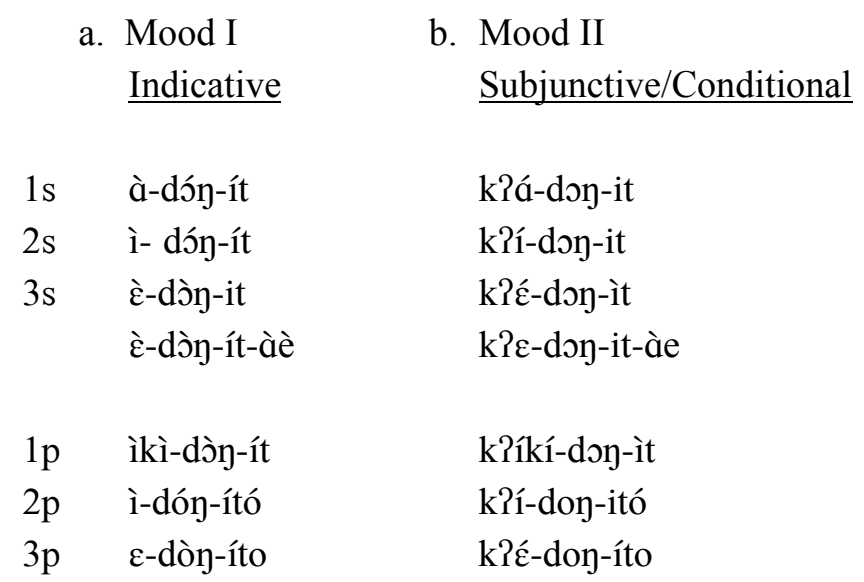

The second type of neutral TMA marker is the suffixal inflection for the aorist past. Due to the predominant presence of voiceless vowels in this inflectional morpheme across moods, and the presence of inactive alternative forms that are not voiceless, I propose that its neutrality results from phonological erosion within a process of historical change. Paradigms are presented in (43) of the [-ATR] verb [ákí-dón] 'to pinch', and phonological neutrality of its inflections can be seen in the retention of the original [ATR] specification of the root vowel after affixation.

$$
\begin{gathered}
\text { ákí-dón - ‘to pinch' } \\
\text { Passive Voice, Aorist Past }
\end{gathered}
$$

\begin{tabular}{|c|c|c|}
\hline aka-don-1́ & k?aka-don-ì & óko-don-ì \\
\hline iki-dóy-í & kPíki-døy-ì & íto-doy-ì \\
\hline a-doy-1́ & kPع-doy-ì & to-doy-ì \\
\hline iki-dóy-ì & kPíki-doy-ì & íto-doy-ì \\
\hline iki-dón-ì & kPiki-døy-ì & íto-dəy-ì \\
\hline a-doy-ì & k?ع-doy-ì & to-don-ì \\
\hline
\end{tabular}
a. Indicative
b. Subj./Cond.
c. Narr./Imperative 
One TMA marker is dominant in some conjugations and neutral in others, and it is considered to be in the midst of historical change. That suffix is [-ere], a Form B marker of the present and past continuous aspect seen in (44). In both active and passive voice of the indicative mood, the marker spreads a [+ATR] specification leftward when affixed directly to the root. However, in the active voice the spreading does not occur when derivational suffixes intervene, a situation occurring only with this TMA marker and none other. Examples (44a) through (44g) show cases of dominant [+ATR] spreading; especially notable is the alternation of narrative mood pronominal prefix [-oko] in (44b). Examples (44d) through (44g) show spreading across the frequentive morpheme [-eenen].

(44) Infinitive: ákí-dón - 'to pinch'

a. aka-don-eré 1s-pinch-B.ACT. IND.PST PROG

'I was pinching'

b. oko-don-ere

NAR.1s-pinch-B.ACT.NARR.PST PROG

'....and I was pinching'

c. káka-don-eré

1s-pinch-B.ACT.SUBJ.PST.PROG

'if I were pinching...'

d. $\varepsilon$-dón-éenén-é-éré

3s-pinch-FREQ-B.PASS.IND. FUT

'He will be frequently pinched'

e. aka-dón-éenén-é-eré

1s-pinch- FREQ-B.PASS.IND.FUT

'I will frequently be pinched' 
f. a-doy-eenen-e-eré 3s-pinch- FREQ- B.ACT.IND.PST PROG

'He was frequently pinching.'

g. aka-don-eenen-e-eré 1s-pinch- FREQ-B.PASS.IND. PST PROG

'I was frequently being pinched'

The examples in (45) show those cases in which the lack of spreading co-occurs with intervening derivational suffixes, as evidenced by the lack of alternation in the root vowel [0]. It can be noted here that the relevant derivational suffixes include the frequentive [-eenen], the itive, and the dative/applicative. The TMA marker [-ere] provides the only instance in which these suffixes appear to block harmony, and this state of affairs is attributed to the weakness of the inflection as a harmony trigger.

(45) a. aka-doj-ar-eré

1s-pinch-IT-B.ACT.IND.PST PROG

'I was pinching (away)'

b. $\varepsilon$-doy-éenén-é-éré

3s-pinch-FREQ-B.ACT. IND. FUT

'He will frequently pinch'

c. káka-don-ar-eré

SUBJ.1s-pinch-IT-B.ACT.SUBJ.PST PROG

'if I were pinching (away)...'

d. óko-døn-ar-eré

NAR.1s-pinch-IT-B. ACT.NARR. PST PROG

'....and I was pinching (away)'

e. aka-don-akin-eré

1s-pinch-DAT-B.ACT.IND.PST PROG

'I was pinching (for)' 
6.4 Diachronic Evolution of Frequentive Morphology. Harris (2005) described the development of typologically unusual structures as resulting from a complex series of relatively ordinary diachronic changes. The structures are unusual by virtue of the fact that the diachronic processes occurred together, and in a particular manner and order. Such changes may occur and re-occur within groups of related languages. Previewing a treatise on the proliferation of pronominal prefixes and of noun incorporation processes in Northern Iroquois, Chafe (1999) comments:

Like forests, languages may develop toward a climax stage, where particular combinations of features, like plant communities, may flourish to define a particular language type. I think it useful to think in terms in terms of florescence of linguistic features in this sense- the flowering of features that come to dominate a form that a language takes. [39]

He proceeds to argue that florescence is a force in grammaticalization, allowing Northern Iroquois languages to develop their distinctive characteristics.

An analogous situation occurs with reduplication in the Teso-Turkana cluster, a grouping that includes Karimojong, Turkana, Ateso, Nyangatom, Toposa, Dodoth and Jie. Reduplication has an iterative or frequentive meaning, commonly expressed through whole-verb reduplication, or, as in the case of processes in Karimojong and Turkana, the reduplication of morphemes to create frequentive forms in a phased grammaticalization/incorporation process.

There are four of these frequentive forms in Karimojong, which have cooccurrence restrictions and which appear to follow similar developmental changes. A five-phase grammaticalization and incorporation process is proposed. Each of the four frequentive forms is proposed to be at a different stage in this process, though evidence exists for their having passed through previous stages. The phases are described and illustrated with examples (46) through (50). Support is provided with comparison to analogous forms in Turkana, Ateso and Toposa.

Phase 1: The affix is a TMA marker, neutral under harmony rules. This is proposed to be the result of one or more of the following processes: 1) Phonologically active segmental material is eroded and lost, leaving behind an epenthetic vowel and consonant, which are re-analyzed as neutral markers; 2) Phonologically active material remains, and the meaning of the inactive portion undergoes re-analysis. 
(46) a. à-dón-ít

1s-pinch-ACT. A. PRS.PERF.1s

'I have pinched'

b. غ̀-dón-ito

3p-pinch-ACT. A. PRS.PERF.3p

'They have pinched.'

Phase 2: The affix, or a portion of it, is reduplicated, assumes a frequentive meaning and is at first neutral under harmony. It retains its function as a TMA marker and sits at the right edge of the verbal complex.

a. ì-don-ítít íjòn

2s-pinch-ACT.A.PST.PERF. 2s

'You (s) had frequently pinched/used to pinch.'

b. 1́-dòy-ìtito 1́èz

2p-pinch-ACT.A.PST.PERF. $2 p$

'You (p.) had frequently pinched/used to pinch..'

c. è-tìja-ítít

1s-do-FREQ-PST.PERF

'I used to do'

Phase 3: The affix assumes status of derivational suffix with a frequentive meaning, while remaining neutral to harmony processes. Other TMA markers take the rightmost slot reserved for suffixal inflectional markers, or the phonological material, active or not, of the old marker remains. 
(48)

a. ì-dòn-éenèn-èt íjòn

2-pinch-FREQ-PRS.PERF. 2s

'You (s) have frequently pinched'

b. ì-dòn-eenen-eto íèz

2-pinch-FREQ-PRS.PERF. 2p

'You (p) have frequently pinched.'

Phase 4: The reduplicated affix participates in harmony processes, but also develops corresponding directional morphemes with which it co-occurs. There are separate generations of these complexes of frequentives with directional morphemes.

a. ábú-ún-ún-ùn

INF-return-FREQ-VEN

'to frequently return this way'

b. ábú-án-án-àr

INF-return-FREQ-IT

'to frequently return that way'

Phase 5: The affix loses the reduplicant. There are co-occurrence restrictions on the morphemes. The [-ùn] ventive co-occurs only with the [-ún] frequentive, and the [-àr] itive co-occurs only with the [-án] frequentive.

The morpheme [-éenen] in Karimojong takes no directional suffixes, and is shown in (50f). The ventive and the itive may be affixed separately without frequentives, as seen in (50d) and (50e). In Karimojong the [-án] and [-ún] frequentives are never affixed without their corresponding directional affixes. The verb root can also be reduplicated to express iteration, although this form can assume alternative meanings. This process may co-occur with the itive or ventive. Forms with iterative reduplication appear in $(50 \mathrm{~g})$ and $(50 \mathrm{~h})$; examples $(50 \mathrm{i})$ and $(50 \mathrm{j})$ have alternative meanings. 
a. á-bú-ún-ùn

INF-return-FREQ-VEN

'to frequently return this way'

c. ákí-nók-ún-ùn

INF-light fire- FREQ-VEN

'to light a fire this way'

e. á-sá-ùn

INF-go slowly- VEN

'to go slowly this way' b. á-bú-án-àr

INF-return-FREQ-IT

'to frequently return that way'

d. áki-bú-òr

INF-knock down-IT

'to knock down that way'

f. á-bú-éenén

INF-return-FREQ

'to return frequently'

g. ákí-sứb

'to create'

ákí-sứb-ú-súb

'to create repeatedly'

ákí-sứb-ú-sưb-ú-ùn

'to create repeatedly (this way)'

ákí-súb-ú-súb-jàr

'to create repeatedly (that way)'

h. ákì-cưm

'to pierce'

ákì-cúm-ú-cúm

'to pierce repeatedly'

ákì-cúm-Ú-cúm-ú-ùn

ákì-cúm-ú-cúm-jàr

'to pierce repeatedly (this way)'

'to pierce repeatedly (that way)'

i. ákì-dón

'to castrate'

ákì-doy-i-dòn ${ }^{23}$

'to keep cattle moving with clicks of the tongue'/

'to tell oxen epics'

ákì-don-ó-dòn

'to castrate repeatedly'

${ }^{23}$ Class 2 verbs are normally reduplicated with the [i]. Its use here to convey alternate meaning and use of stem vowel [o] for conventional iteration are reported to confuse even native speakers. 


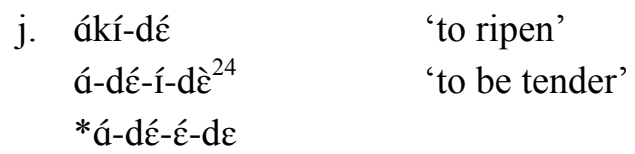

The co-occurrence restrictions and the incomplete assimilation of [-ún-ùn] into Level 1 vowel harmony rules - shown in (24) and (25) and visible once more in a comparison of (50a) with (50c) — are indicative of evolutionary processes. Morpheme specialization and the loss of productivity occur when there are alternative means of expressing the same concept. The complete assimilation of [-ánàr] into Level 1 phonology versus the partial assimilation of [-únùn] indicates that [-ánàr] is the older form. The rise of [-eenen] as an alternative accompanies restrictions on the use of the [-án] and [-ún] frequentives, and fills the void created by assigning specialized meanings to forms with iterative reduplication. The dual functions of [-itit] as a frequentive suffix and a perfective TMA marker, along with its limited distribution, point toward the origin and trajectory of such forms.

A comparison to analogous structures in Turkana supports this proposal. According to Dimmendaal (1983: 107-118) the habitual marker [-een], a frequentive marker used for dynamic verbs, has an older reduplicated form [-enen] that is used interchangeably; the form in northern dialects uses the palatal glide [-jeen]. Data are shown in (51). The alternation of the [-ATR] root vowel in [-ìm $\underline{y}]$ to its [+ATR] counterpart in the derived form shows that this frequentive verb extension can trigger suffix-controlled [+ATR] harmony, unlike its Karimojong counterpart. The suffixal inflection of the infinitive form, an eroded voiceless vowel, does not trigger harmony. Example sentences are shown in (52).
a. - ram
'to beat'
a-ram-(j)een-ì/a-ram-enen-ì
'to beat frequently'
b. -ìmúf
'to eat'
ak-ìmüf-(j)een-ì / ak-ìmüdz-enen-ì
'to eat regularly'

\footnotetext{
${ }^{24}$ Class 1 verbs such as this will normally use the stem vowel, in this case $[\varepsilon]$, for reduplication.
} 

a. ̀̀-ràm-een-è
yesì
a-ber-ù kẹ’
3-beat-FREQ-IPFV.s 3s-M wife 3s-POSS-M

'He beats his wife frequently.'

b. غ̀-lòs-een-e-tè kecì lòdwar'

3-go-FREQ-IPFV-3p3p Lodwar

'They go to Lodwar from time to time.'

This habitual marker in Turkana faces no co-occurrence restrictions and is used with the ventive, itive or the applicative. When it is, it assimilates the vowel of these suffixes, thereby becoming recessive in the face of a root-controlled [ATR] harmony domain. The indexed assimilation rule proposed by Dimmendaal (1983:118) appears in (53). Examples with the itive are shown in (54).

$$
\text { -een- } \rightarrow \mathrm{V}_{\mathrm{i}} \mathrm{V}_{\mathrm{i}} \mathrm{n}-\quad / \_\left\{-\mathrm{V}_{\mathrm{i}} \mathrm{r},-\mathrm{V}_{\mathrm{i}} \mathrm{kin},-\mathrm{V}_{\mathrm{i}} \mathrm{n}\right\}
$$
a. -bon 'to return'
a-bon-oon-òri 'to go to and fro'
b. (root absent)
a-tik-oon- òri 'to rape, violate'
c. -IIr
'to hear'
ak-ìrr-aan-àrı 'to hear from time to time'
d. -ìlot
'to wash'
ak-ìlot-aan-àrı 'to wash regularly'

The frequentive [-An] in Karimojong is analogous to the frequentive morpheme for stative verbs in Turkana, the surface forms of which have long vowels and select [a/o] forms according to the [ATR] specification of the verb. Its use is independent of the itive. Sample verb forms are presented in (55) and their use in context appears in (56). In some instances the $/ \mathrm{n} /$ coda is replaced with [k]. Data are taken from Dimmendaal (1983: 108-109). 
(55)
a. - - jok
'to lie'
a-ljok-oon-ò
'to be mendacious'
b. $-p \varepsilon g$
'to argue'
a-peg-aan-à
'to be argumentative'

(56)
a. è-ljòk-oo-n-à I-kòku eenì
b. $\grave{\varepsilon}$-pèg-aa-k-à
kèci
3-lie-FREQ-s-V child this
'This child is mendacious.'
3-argue-FREQ-p-V 3p
'They are argumentative.'

The Turkana itive and the ventive are fully integrated into the [ATR] harmony system and may be used independently. Infinitive forms carry the voiceless vowel extension [-i]. Like the Karimojong form in (25b), the [-Ùn] ventive, the [-Àr] itive and the dative/applicative [-Akin] in Turkana may drop their final sonorants before a pause and optionally de-voice the preceding vowel [-vo/-u], [a/o], [-ki]. Examples taken from Dimmendaal $(1983: 375,118,481-483,62-63,190,112)$ appear in (57). The ventive appears in (57a) through (57d), the dative /applicative in (57e) through (57h), and the itive is shown in (57i) and (57j).

a. to-rjam-̀̀

yesì $\quad$ jI-kààl-a $\quad \varepsilon$-dak-a-sì

NARR.PST.3-find-VEN 3s camels 3-graze-V-p

'...and he found the camels grazing.'

b. ̀-à-dàìdà-un-ì @ ya-muk' kay

3-PST-finish.ITV-VEN-PST.p shoes 1s-POSS

'My shoes were completely worn out.'

c. غ̀-a-potò̀ yi-tùnà k-idjat-u-idjat-un-oe

3-PST-come people 3-abound.ICP.ITV-VEN-IPFV.3s

'The people began to come in one by one.'

d. k-idon e-nàtun è-kùr-i `a-koomwa` to-kur-ù 3-remain lion 3-dig-IPFV anthill NARR.3s-scratch-VEN

'The lion remained there, scratching the anthill.' 
e. ¿̀-ìn-akın-ì yesì I-tuanì lo’ ak-ìmuj

3s-give-APP-FUT 3s person this food

'She will give this person some food.'

f. to-ram-akì yesi yikiljok' lu’ ya-kan-ì

NARR.3-beat-APP 3s p.man DEM p-hand

'He clapped his hands for these men.'

g. áki-bús-ókín-or-è

INF-throw-DAT-VEN-SUBJ

'to throw oneself down, 25

h. to-rot-okì yesì è-rwò-si yi-coro-i ` è-bàa-sì $t \int \varepsilon m, t \int \varepsilon m, t \int \varepsilon m$

NARR.3-go-APP3s 3-shake-p bells 3-say-p (sounds)

'And he went off again, his shaking bells making a lot of noise.'

i. kà-inò $\varepsilon$-min-àr-è nèsi

why 3-love-IT-SUBJ 3 s.F

'Why is she loved?'

j. a-limw-òr-i

INF-tell-IT-INF

'to confess'

Comparison of the frequentive, itive and ventive forms in Karimojong and Turkana supports the evolutionary proposal for Karimojong morphemes. The forms in Turkana in some cases appear to be at more advanced stages in the evolutionary process, while in other cases it could be proposed that the Karimojong forms are the vanguard. While the [-Ún-] frequentive in Karimojong is not completely integrated into the vowel harmony system of the language, and co-occurs with the [-Ün-] ventive, in Turkana it fully participates in vowel harmony rules and has no co-

${ }^{25}$ As this is a reflexive construction, the infinitive here appears without a voiceless vowel.

${ }^{26}$ The itive marker here with the subjunctive provides an impersonal active meaning to the verb. 
occurrence restrictions, indicating the possible evolutionary path for its Karimojong counterpart. The loss of the reduplicant for the Turkana [-een-] frequentive and the free variation with older reduplicated forms likewise shows one possible path for the [-eenen-] frequentive in Karimojong. The use of this form in Turkana only for dynamic verbs and the rule shown in example (53) stipulating that its vowels adopt the values of the vowels of the ventive, itive and applicative morphemes under conditions of co-occurrence indicate a specialization that the Karimojong [-eenen] may one day adopt, and at the same time suggest the origin of the Karimojong cooccurrence structures [-ÚnÙn-] and [-ÁnÀn-], in which the frequentive morphemes share the same tonal value and appear to have been simplified to containing only one short vowel.

Further confirmation of this evolutionary process as evidence of florescence is found in the limited data available from Ateso, an Eastern Nilotic language of Uganda and Kenya. Ngoro, its standard dialect, possesses a $76 \%$ lexical similarity with Turkana, and a 75\% lexical similarity with Karimojong (Lewis, 2009). Like Karimojong and Turkana, it is a VSO language with [ATR] harmony and tone, and manifests much of the inflectional and derivational morphology found in both languages. Nevertheless, the data below are written not in IPA but in the modified version of the orthography first developed under colonial rule.

Ateso verbs have reduplicated forms that express intensified or repeated action, as seen by the data in (58a) and (58b) (Hilders \& Lawrence, 1958:16; Kitching, 1915: 41). The reduplication can also take on more figurative meanings as seen in (53c) and (53d).

(58)
a. ai-nom
INF-beat
'to strike, beat'
c. ai-lam
INF-jump
'to jump'
b. ai-noma-noma
INF-beat-beat
'to give a beating'
d. ai-lama-lama
INF-jump-jump
'to jump to and fro'

Ateso has the frequentive/repetitive [-enene] similar to both Karimojong and Turkana, and it shows evidence of morphological reduplication. Examples (59a) 
through (59c) show infinitive and derived forms of [-mat] 'drink' (Hilders \& Lawrence, 1958: 9; Kitching, 1915: 40).
a. ai-mat
b. a-mas-enene
c. i-mas-enene-te
INF-drink
1s-drink-FREQ-s
2p-drink-FREQ-pl
'to drink'
'I always drink.'
'You(p) always drink.'

Ateso also has the [-an/-on] frequentive, tied in meaning to the reciprocal and cooccurring with the [-ar/-or] itive forms (Hilders \& Lawrence, 1958: 3; Kitching, 1915: 40). Example (60a) shows the infinitive form of [-nit/nit] 'ask,' which can be compared to the derived form in $(60 \mathrm{~b})$ bearing frequentive and itive suffixes. Example (60c) shows that the frequentive form can be reduplicated. These examples suggest that the origin of the reduplicated frequentive may lie in the expression of reciprocity.
a. ai-nit/ aki-nit
b. aki-nit-an-ar-i
INF-ask
INF-ask-FREQ/RCP-IT-INF
'to ask'
'to ask often/one another'
c. aki-nom-anan-ar-i
d. ko-tir-on-or-os
INF-beat-FREQ/RCP-IT-INF
IMP-touch-FREQ/RCP-IT-IMP
'to beat one another'
'Touch each other.'

That the evolution of the frequentive morphemes is an example of florescence in Karimojong, Turkana and Ateso is a conclusion that can be gleaned through a comparison with Toposa (Schroeder \& Schroeder, 1984). Toposa has the morphology common to Nilotic, but which does not, at least in the published data, show evidence of the aforementioned process of reduplication and genesis of the frequentive/habitual morphemes. Toposa does have whole root reduplication as an expression of the intensive, as seen in (61). 
(61)
a. a-pet-e-pes-i
b. a-dam-a-dam - i
1s-kick-and-kick-np ${ }^{27}$
1 s-dance-and-dance-np
'I kick repeatedly.'
'I dance the war dance'.

The frequentive or habitual in Toposa occurs generally with long vowels and without the [n] consonant found in Turkana, Karimojong and Ateso. This can be seen in examples (62a) through (62c). However, to avoid clusters of three vowels, [n] is inserted with vowel shortening, as seen in (62d), (62e) and $(62 \mathrm{~g})$ [23, 24]. Nonetheless, in Eastern Toposa the habitual of dynamic verbs is formed like that of Turkana, an example of which is shown in $(62 \mathrm{~h})$. Toposa also has the [a/o] alternating itive and frequentive, evident in examples (62e) through (62g).

a. a-per-oo-no

1s-sleep-FREQ-np

'I am sleepy.'

c. $\varepsilon-\jmath \jmath k-\Lambda \Lambda-n \Lambda$

3s-good-FREQ-np

' $\mathrm{He} / \mathrm{she}$ is good.'

e. e-in-an-ar-i

3s-give-FREQ-IT-np

'He gives away regularly.'

g. e-buk-on-un-i

3s-pour-FREQ-VEN-np

'He pours in regularly.' b. kI-mUJ- $\Lambda \Lambda-\mathrm{n} \Lambda$

1p-eat-FREQ-np

'We are fond of eating.'

d. e-in-an-akin-i

3s-give-FREQ-DAT-np

'He gives to somebody regularly.'

f. a-buk-or-i

1s-pour-IT-np

'I pour out.'

h. a-per-een-e

1s-sleep-FREQ-np

'I sleep regularly.'

Like Karimojong and Turkana, Toposa has the [-Un] ventive, which participates in vowel harmony and has various allomorphs, which are presented in (63). The latter shows de-voicing of the vowel in the absence of the alveolar nasal word-finally, although unlike in Karimojong, the elision of the alveolar nasal does not affect [ATR] feature profile [25,26].

${ }^{27} \mathrm{np}=$ non-past 
(63)
a. a-lac-un- 1
b. to-rut-o
c. a-lac-u
1s-dress-VEN-PST
IMP-uproot-VEN
1s-dress-VEN
'I undress.'
'Uproot!'
'I had dressed.'

The evolution of frequentive morphemes through reduplication, differentiation, and simplification in Karimojong, Turkana and Ateso can be taken as an example of florescence characteristic of these closely related languages in the Teso-Turkana cluster. Like morphemes in Toposa, a related language, do not retain evidence of this process, either because it did not occur, the forms have long been simplified or remain unreported. However, whole verb reduplication as an expression of repeated or intensive action is retained, similar to other languages of the cluster.

\section{Conclusions}

Analysis of the data establishes a correspondence between the affixation of specific morphemes and the application of a defined set of phonological processes. It supports the view that there are three morpho-phonological levels in Karimojong, proposed to correspond to stages in the historical evolution of the language. The argument for historical evolution can be made by correlating the morphemes by their levels of affixation to the stages in the cross-linguistically attested agreement system grammaticalization cline, and by taking into account affix-ordering universals. These indicate that the structure of inflection on the Karimojong verbal complex results from the cline operating on both the right and left peripheries as a result of historical word order change, for which a model has been presented. Affixes undergoing phonological processes corresponding to different levels in different contexts are proposed to be in transition between levels, or in processes of incorporation or attrition. It is proposed that the genesis and evolution of frequentive morphemes has been recurrent in the history of Karimojong, leaving separate generations of morphemes with co-occurrence restrictions. This evolutionary process is confirmed through comparison to Turkana, which once formed part of the same language, and to Ateso and Toposa, also part of the Eastern Nilotic subgroup. Overall, this paper has demonstrated the value of [ATR] harmony patterns as a tool for historical reconstruction. 
A precise accounting of the innovation triggers at each historical stage has yet to be carried out, and is left to future research. Likewise, comparisons to other historically-related languages and investigation into sources of contact outside the language family remain topics for future studies.

\section{Appendix A: Guide to Selected Karimojong Affixal Morphemes}

\begin{tabular}{|c|c|c|c|}
\hline Level & Morpheme & Examples & $\begin{array}{c}\text { [ATR] Feature } \\
\text { Spread }\end{array}$ \\
\hline 1 & $\begin{array}{l}\text { Narrative mood } \\
\text { pronominal Prefix } \\
\text { (at)OO- } \\
\text { itO- } \\
\text { tO- }\end{array}$ & $\begin{array}{l}\text { oo-doneenente-'...that } \\
\text { had/has/have freq. } \\
\text { pinched' } \\
\text { to-donunì -'...that is } \\
\text { castrating/will castrate } \\
\text { for...' } \\
\text { to-doyàè-'.... and he was } \\
\text { pinched'. }\end{array}$ & $\begin{array}{l}\text { Vowel varies with the } \\
\text { [ATR] specification of } \\
\text { verb root; recessive } \\
\text { subsequently. }\end{array}$ \\
\hline 1 & $\begin{array}{l}\text { Infinitive prefix } \\
\text { akI- } \\
\text { a- }\end{array}$ & $\begin{array}{l}\text { ákí-dón - 'to pinch' } \\
\text { áki-doy- 'to castrate' } \\
\text { ákí-be- 'to agree } \\
\text { á-òlì - 'to get lost' }\end{array}$ & $\begin{array}{l}\text { Archiphonemic (I) } \\
\text { vowel assumes root } \\
\text { [ATR] specification; } \\
\text { recessive } \\
\text { subsequently. }\end{array}$ \\
\hline 1 & $\begin{array}{l}\text { Causative Prefix } \\
{[\mathrm{t}+\text { stem vowel }]} \\
\text { Class } 1 \text { verbs. } \\
{[\mathrm{z}+\mathrm{i} / \mathrm{I}-] \text { for Class }} \\
\mathrm{II} \text { verbs. } \\
/ \mathrm{t} / \rightarrow[\mathrm{z}] \\
/ \quad\{\mathrm{i}, \mathrm{I}\}\end{array}$ & $\begin{array}{l}\text { Éké-tá-càpì-'I shall cause } \\
\text { you to weed.' } \\
\text { ákızílìp- 'to cause to pray' } \\
\text { aki-zi-doy-'to cause to } \\
\text { castrate' }\end{array}$ & $\begin{array}{l}\text { [ATR] specification } \\
\text { varies according to } \\
\text { root and by rule } \\
\text { according to verb } \\
\text { class; recessive } \\
\text { subsequently. }\end{array}$ \\
\hline 1 & $\begin{array}{l}\text { [-Ún]-' often' } \\
\text { [-Ùn]-'this } \\
\text { way, toward' }\end{array}$ & $\begin{array}{l}\text { ákísáùn-'often go slowly' } \\
\text { ákìbúùn-'often knock } \\
\text { down' }\end{array}$ & $\begin{array}{l}\text { Vowel alternates } \\
\text { according to the root } \\
{[\mathrm{ATR}] \text { value in }}\end{array}$ \\
\hline
\end{tabular}




\begin{tabular}{|c|c|c|c|}
\hline & $\begin{array}{l}\text { [-ÚnÙn]-(above) } \\
\text { compounded }\end{array}$ & $\begin{array}{l}\text { á-dón-únùn- 'often pinch } \\
\text { this way' }\end{array}$ & $\begin{array}{l}\text { absence of consonant } \\
\text { coda; }[+ \text { ATR }] \\
\text { specification } \\
\text { elsewhere. }\end{array}$ \\
\hline 1 & $\begin{array}{l}\text { Derivational } \\
\text { suffixes with } \\
\text { Characteristic } \\
\text { Vowels } \\
\text { [-(a/o)n - FREQ } \\
\text { [-(a/o)r] - IT } \\
\text { [-(a/o)kin]-DAT/ } \\
\text { APPL }\end{array}$ & $\begin{array}{l}\text { ádonàr- 'pinch away from' } \\
\text { ákìbúòr-'knock down } \\
\text { away from' } \\
\text { ásákìn -'go slowly for' }\end{array}$ & $\begin{array}{l}\text { Suffixes with [a] for } \\
\text { [-ATR] verbs. } \\
\text { Suffixes with [o] for } \\
\text { [+ATR] verbs. Values } \\
\text { are assigned on Level } \\
1 \text { only. }\end{array}$ \\
\hline 1 & [-òr] Itive & $\begin{array}{l}\text { ákídón-òr- 'castrate away } \\
\text { from' } \\
\text { í-dónódón-ó-or-jatà - } \\
\text { '...they (will) repeatedly } \\
\text { castrate' }\end{array}$ & $\begin{array}{l}\quad \text { Drives a dominant } \\
\text { bi-directional }[-\mathrm{ATR}] \\
\text { mini-domain in verb } \\
\text { forms with original } \\
\text { [+ATR] roots. }\end{array}$ \\
\hline 1 & 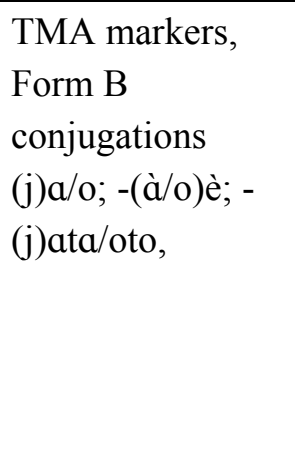 & 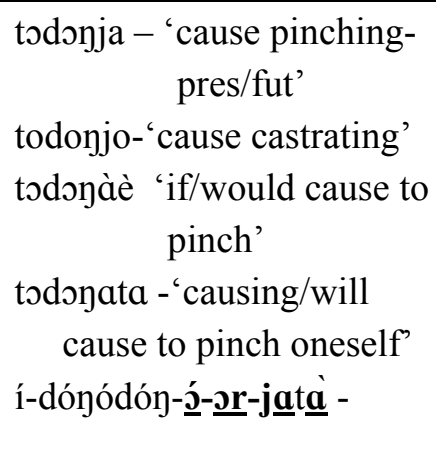 & $\begin{array}{l}\text { Suffixes with [a] for } \\
\text { [-ATR] verbs. } \\
\text { Suffixes with [o] for } \\
\text { [+ATR] verbs } \\
\text { Values assigned on } \\
\text { Level 1 } \\
\text { Selected for [-ATR] } \\
\text { verbs under [-ATR] } \\
\text { dominant suffixation }\end{array}$ \\
\hline
\end{tabular}




\begin{tabular}{|c|c|c|c|}
\hline 2 & $\begin{array}{l}\text { TMA Markers, } \\
\text { Form A } \\
\text { conjugations } \\
\text {--o/-jo; -ete, } \\
\text {-(i)tor; -etei } \\
\text {-oe; -(u)ito, } \\
\text {-os; -itere } \\
\text {-ok; -itotor } \\
\text {-okizi; -ì } \\
\text {-ere; itetei } \\
\text {-ozi } \\
\text { [+ATR] }\end{array}$ & $\begin{array}{l}\text { akidonunjo- 'to be } \\
\text { pinching /will pinch } \\
\text { frequently' } \\
\text {-onúnetè -'you s/p pinch } \\
\text { /will pinch frequently' } \\
\text { èdònùnère-'he was } \\
\text { frequently pinched' } \\
\text { ídonúnì - 'you s/p pinch } \\
\text { /will pinch' } \\
\text { todonito- 'have/had caused } \\
\text { to pinch' } \\
\text { to-doy-unun-[+ATR] - } \\
\text { '...and he frequently } \\
\text { pinched/was pinching } \\
\text { this way' }\end{array}$ & $\begin{array}{l}\text { Triggers exhaustive } \\
\text { [+ATR] spreading } \\
\text { leftward. }\end{array}$ \\
\hline 3 & $\begin{array}{l}\text { Frequentive } \\
\text { Suffix/Infix } \\
\text {-eenen(e)- } \\
\text { 'frequently' } \\
\text {-itit-frequently }\end{array}$ & $\begin{array}{l}\text { ikidoneeneneterè 'you } \\
\text { frequently were being } \\
\text { /had been pinched } \\
\text { ákímókiéénén -' to often } \\
\text { handle firmly' } \\
\text { ìdònítít íjòn - You(s) had } \\
\text { frequently pinched.' }\end{array}$ & $\begin{array}{l}\text { Transparent to } \\
\text { harmony. Harmony } \\
\text { affects surrounding } \\
\text { suffixes. }\end{array}$ \\
\hline 3 & $\begin{array}{l}\text { Pronominal Prefix } \\
\text { a- 1s IND CL } 1 \\
\text { i- } 2 \text { s/p IND CL1 } \\
\grave{\varepsilon}-3 \text { s/p IND. CL } 1 \\
\text { iki- 1p IND CL 1/ } \\
\text { PST PASS 2p } \\
\text { aka/oko- 1s } \\
\text { PASS; IND CL1 } \\
\varepsilon k \varepsilon-1 \text { s PASS } \\
\text { IND CL } 2\end{array}$ & $\begin{array}{l}\text { à-dónít - 'I have pinched.' } \\
\text { ì-tòdzóketè - 'You were } \\
\text { causing to be good.' } \\
\text { ع-doyunì- 'He/she was } \\
\text { frequently pinched' } \\
\text { iki-doyunì - 'You were } \\
\text { frequently pinched' } \\
\text { aka-réó áeón -'I am }\end{array}$ & $\begin{array}{l}\text { Transparent to } \\
\text { harmony. }\end{array}$ \\
\hline
\end{tabular}




\begin{tabular}{|c|c|c|c|}
\hline & & $\begin{array}{l}\text { overpowered.' } \\
\text { Éké-tátfàpì-'I shall cause } \\
\text { you to weed.' }\end{array}$ & \\
\hline 3 & $\begin{array}{l}\text { SUBJ/COND } \\
\mathrm{k} ?+\text { (pronominal) }\end{array}$ & $\begin{array}{r}\text { kP-iki-don-àr -'that you } \\
\text { pinch away' }\end{array}$ & $\begin{array}{l}\text { Transparent to } \\
\text { harmony. }\end{array}$ \\
\hline 3 & $\begin{array}{l}\text { TMA Markers } \\
\text {-ere - } \\
\text { PASS.PRS/PST. } \\
\text { PROG } \\
\text {-it- PRS./PST } \\
\text { perfect }\end{array}$ & $\begin{array}{l}\text { akadonarerè- 'I was being } \\
\text { pinched (away)' } \\
\text { àdónít- 'I have pinched' }\end{array}$ & $\begin{array}{l}\text { Transparent to } \\
\text { harmony. }\end{array}$ \\
\hline
\end{tabular}

\section{Appendix B: Inventory of Karimojong Vowels}

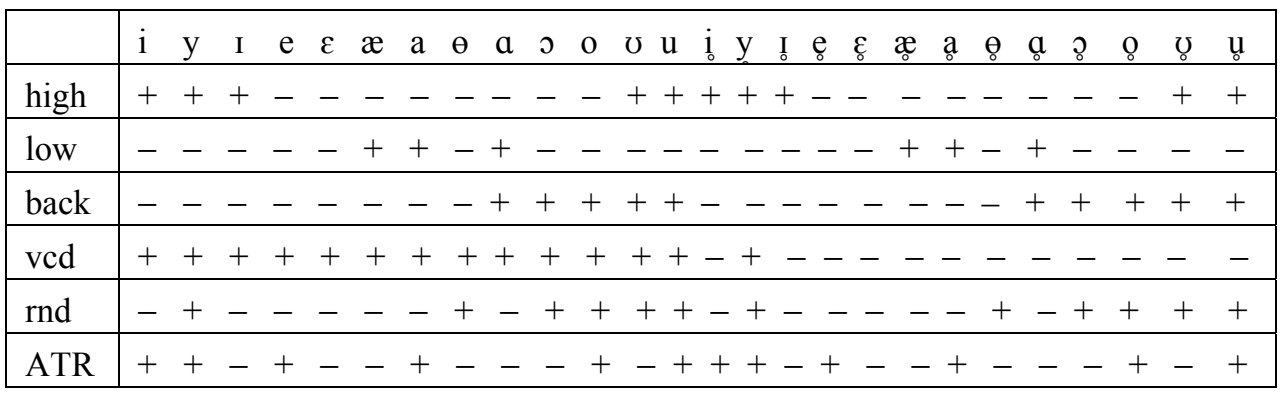




\section{Appendix C: Attrition and Loss in Karimojong Verbal Paradigms}

Paradigms of the aorist past tense exhibit the erosion of suffix vowel voicing and the loss of entire suffixes. With the exception of alternate third person singular forms, indicative and narrative mood forms express the singular through the absence of suffixal inflection, which likewise appears in the first person plural in the indicative mood. Plural number is coded by a suffix vowel, which is voiceless in the second and third person plural of the indicative mood, and fully voiced in the narrative mood, with a low tone marking the first person plural.

Verb: akıdøy - 'pinch’ Form A, Aorist Past, Active Voice, Class 1

a. Indicative Mood

1s à-dón 'I pinched.'

2s ì-dón 'You pinched.'

3s à-don 'He/She/It pinched.' a-doní

$1 p$ ìkì-don 'We pinched.'

$2 \mathrm{p}$ ì-dona 'You pinched.'

$3 p$ à-dòyà 'They pinched.' b. Narrative Mood

\begin{tabular}{|c|c|}
\hline (àt)ว̀ว-don & '....and I pinched.' \\
\hline tò-don & '....and you pinched.' \\
\hline & '....and he/she/it pinched \\
\hline o-do & \\
\hline & à ' ....and we pinched.' \\
\hline & ‘...an \\
\hline d & they pin \\
\hline
\end{tabular}

The reflexive voice, imperfective aspect past tense shows greater variety in patterns of erosion. The paradigm represented in (a) shows singular forms and the first person plural exhibiting the loss of the timing units and segmental material of the suffix, but retaining the dominant [+ATR] feature, which triggers a leftward spread of suffixcontrolled [+ATR] harmony changing the [ATR] value of the verb root. Second and third person plural have retained the timing units and feature profiles of the suffix. In (b), singular forms the presence of a suffix is marked only through an active [+ATR] feature. Plural forms vary freely between a phonologically active [+ATR] suffix with segmental material and one without. Paradigm (c) shows complete erosion of suffixes representing the first person plural and all singular forms, while the alternative third person singular and the second and third person plural have suffixes that are phonologically inactive as triggers for [ATR] feature spreading. 
a Form A, Reflexive Voice, Imperfective Aspect, Past/Past Continuous Tenses Position 6: (Frequentive, Ventive) Position 3: (Itive) ákídónúnún ákídónár
a. Indicative Mood
b. Narrative Mood
1s à-dòn-únún[+ATR]
(àt)òo-doy-unun [+ ATR]
c. Indicative Mood
2s ì- dòn-únún[+ ATR]
tò-doy-unun [+ ATR]
3 s à-dòy-ùnun [+ATR]
to-doy-unun- [+ ATR]
à-dòy-ùnùn-oi
to-don-unun-etè̀ ${ }^{28}$
ì-dón-ár
غ̀-dòn-ar
غ̀-dòy-ar-òi
1p ìkì-dòy-ùnun[+ ATR]
(at)oo-don-unun-(os)
ìkì-dón-ár
2p ì-dòy-unun-ozì
tò-don-unun-(os)
ì-dón-ár-ozi
$3 p$ à-dòn-ùnùn-ozì
to-doy-unun-(os)
غ̀-dòy-ar-ozì

\section{References}

Akinlabi, Akinbiyi. 1994. Alignment constraints in ATR harmony. Studies in the Linguistic Sciences 24(1). 1-18.

Archangeli, Diana. 2003. Vowel harmony and transparency in Wolof: An Ultrasound Study. Colloquium presented at the University of Arizona, November, 2003.

Bell-Berti, Frederica. 1973. The velopharyngeal mechanism: An electromyographic study. New York, NY: The City University of New York dissertation.

Bell-Berti, Frederica. 1975. Control of pharyngeal cavity size for English voiced and voiceless stops. Journal of the Acoustical Society of America 57(2). 456-461.

Bell-Berti, Frederica. 1980. The velopharyngeal function: A spatio-temporal model. Haskins Laboratories Status Report on Speech Research, SR-63-64, 41-65. New Haven, CN: Haskins Laboratories.

Benus, Stefan \& Gafos, Adamantios. 2007. Articulatory characteristics of Hungarian 'transparent' vowels. Journal of Phonetics 35. 371-306.

Bermudez-Otero, Ricardo. 2007. Diachronic phonology. In Paul de Lacy (ed.) The Cambridge Handbook of Phonology, 497-517. Cambridge: Cambridge University Press.

\footnotetext{
${ }^{28}$ This ending also corresponds to past perfect tense, narrative mood, passive voice.
} 
Blevins, Juliette. 2004. Evolutionary phonology. Cambridge: Cambridge University Press.

Booij, Geert. 1988. On the relation between lexical and prosodic phonology. In Pier Marco Bertinetto and Michele Loporcaro (eds), Certamen phonologicum: Papers from the 1987 Cortona Phonology Meeting, 63-75. Turin: Rosenberg \& Sellier.

Booij, Gert. 1992. Lexical phonology and prosodic phonology. In Wolfgang Dressler, Hans C. Luschutzky, Oskaar E. Pfeiffer \& John Rennison (eds.) Phonologica 1988, 49-62. Cambridge: Cambridge University Press.

Booij, Gert \& Jerzy Rubach. 1984. Morphological and prosodic domains in lexical phonology. Phonology Yearbook 1, 1-27. Cambridge: Cambridge University Press.

Bybee, Joan. 1985. Morphology: A study of the relation between meaning and form. Amsterdam: John Benjamins.

Bybee, Joan. 2001. Phonology and language use. Cambridge: Cambridge University Press.

Casali, Rodric F. 2003. [ATR] value asymmetries and underlying vowel inventory structure in Niger-Congo and Nilo-Saharan. Linguistic Typology 7: 307-382.

Chafe, Wallace. 1999. Florescence as a Force in Grammaticalization. In Spike Gildea (ed.), Reconstructing Grammar: Comparative Linguistics and

Grammaticalization, 39-64. Amsterdam/Philadelphia: John Benjamins.

Chung, Sandra. 1977. On the gradual nature of syntactic change. In Charles N. Li (ed.) Mechanisms of Syntactic Change, 3-55. Austin \& London: University of Texas Press.

Cole, Melvyn Douglas. 2009. Null subjects: A reanalysis of the data. Linguistics 47(3). 559-587.

Dimmendaal, Gerrit. 1982. Non-Voiced Vowels in Turkana: A Nilo-Saharan Feature? In Franz Rottland (ed.) Collected Seminar Papers 1979-1980. Nairobi: Nairobi University.

Dimmendaal, Gerrit. 1983. The Turkana language. Dordrecht: Foris Publications.

Dimmendaal. Gerrit. 1991. The geometry of verb paradigms in Teso-Turkana. In Frans Plank (ed.) The Economy of Inflection, 275-306. Berlin, New York: Mouton de Gruyter. 
Dimmendaal, Gerrit. 2002. Constraining disharmony in Nilotic: What does an optimal system look like? Journal of African Language and Linguistics 23(2). 153-181.

Dimmendaal, Gerrit. 2005. Head marking, dependent marking and constituent order in the Nilotic area. In F.K. Erhard Voeltz (ed.) Studies in African Linguistic Typology,71-92. Amsterdam/ Philadelphia: John Benjamins.

Fuss, Eric. 2004. The rise of agreement: A formal approach to the syntax and grammaticalization of verbal inflection. Frankfurt: Johann Wolfgang Goethe Universität dissertation.

Gabelentz, George von der. 1891. Die Sprachwissenschaft. Ihre Aufgaben, Methoden, und bisherigen Ergebnisse. Leipzig: Weigel.

Gick, Bryan, Douglas Pulleyblank, Fiona Campbell \& Mutaka, Ngessimo. 2006. Low vowels and transparency in Kinande vowel harmony. Phonology 23: 1-20.

Guion, Susan, Mark Post \& Doris Payne. 2004. Phonetic correlates of tongue root contrasts in Maa. Journal of Phonetics 32: 517-542.

Givón, Talmy. 1971a. On the verbal origin of the Bantu verb suffixes. Studies in African Linguistics 2(2): 145-163.

Givón, Talmy. 1971b. Historical syntax and synchronic morphology: An archeologist's field trip. Chicago Linguistic Society 7. 394-415.

Givón, Talmy. 1975a. Serial verbs and syntactic change: Niger Congo. In Charles Li (ed.) Word Order and Word Order Change. Austin: University of Texas Press.

Givón, Talmy. 1975b. Topic, pronoun and grammatical agreement. In Charles N. Li (ed.). Subject and Topic, 151-188. New York: Academic Press.

Givón, Talmy. 1976. On the SOV reconstruction of Southern Nilotic: Internal evidence from Toposa. In Larry M. Hyman, Leon C. Jacobson \& Russell G. Schuh (eds.) Papers in African Linguistics in Honor of Wm. E. Welmers. Studies in African Linguistics, Supplement 6: 73-93.

Givón, Talmy. 1977. The drift from VSO to SVO in Biblical Hebrew: The pragmatics of tense-aspect. In Charles N. Li (ed.) Mechanisms of Syntactic Change, 181-254. Austin \& London: University of Texas Press.

Givón, Talmy. 1979a. Language typology in Africa: A critical view. Journal of African Languages and Linguistics 1(2): 199-224.

Givón, Talmy. 1979b. On understanding grammar. New York: Academic Press. 
Goldsmith, John. 1976. An overview of autosegmental phonology. Linguistic Analysis 2: 23-68.

Goldsmith, John. 1990a. Autosegmental and metrical phonology. Cambridge, MA: Basil Blackwell.

Greenberg, Joseph. 1963. Some universals of grammar with particular reference to the order of meaningful elements. In Joseph Greenberg (ed.) Universals of Language, 73-113. Cambridge: MIT Press.

Guion, Susan, Mark Post \& Doris Payne. 2004. Phonetic correlates of tongue root contrasts in Maa. Journal of Phonetics 32. 514-542.

Hall, R.M.R. \& Creider, Chet (1998). The Fates of [+ATR] /a/ in Nilotic. In Ian Maddieson and Thomas J.Hinnebusch (eds.) Language History and Linguistic Description in Africa. Trenton, N.J./Asmata, Eritrea: Africa World Press.

Harris, Alice. 2005. The challenge of typologically unusual structures. In Morphology and Linguistic Typology: Online Proceedings of the Fourth Mediterranean Morphology Meeting, Catania, September 21-23, 2003.

Harris, Alice \& Lyle Campbell. 1995. Historical syntax in cross-linguistic perspective. Cambridge: Cambridge University Press.

Harris, John. 2006. The phonology of being understood: Further arguments against sonority. Lingua 116. 1483-1494.

Heine, Bernd. 1976. A typology of African languages based on the order of meaningful elements. Berlin: Dietrich Reimer Verlag.

Heine, Bernd. 1980. The non-Bantu languages of Kenya. Berlin: Dietrich Reimer (Language and Dialect Atlas of Kenya 2).

Heine, Bernd. 1986. The rise of grammatical categories: Cognition and language change in Africa. Sixteenth Annual Hans Wolff Memorial Lecture. Bloomington, Indiana: African Studies Program, Indiana University.

Heine, Bernd \& Mechthild Reh. 1984. Grammaticalization and re-analysis in African languages. Hamburg: Buske.

Heine, Bernd, Ulrike Claudi \& Friederike Hünnemeyer. 1991. Grammaticalization: A conceptual framework. Chicago/London: University of Chicago Press.

Heine, Bernd \& Tania Kuteva. 2002. World lexicon of grammaticalization. Cambridge: Cambridge University Press.

Heine, Bernd \& Tania Kuteva. 2007. The genesis of grammar. Oxford: Oxford University Press. 
Heine, B. \& Kyung-An Song. 2011. On the grammaticalization of personal pronouns. Journal of Linguistics 1-44.

Hilders, J.H. \& J.C.D. Lawrence. 1957. An introduction to the Ateso language. Kampala, Nairobi, Dar-Es-Salaam: The Eagle Press, East African Literature Bureau.

Hilders, J.H. \& J.C.D. Lawrence. 1958. An English-Ateso and Ateso-English Vocabulary. Kampala, Nairobi, Dar-Es-Salaam: The Eagle Press, East African Literature Bureau.

Hock, Hans Heinrich. 1991. Principles of historical linguistics, $2^{\text {nd }}$ edn. Berlin, New York: Mouton de Gruyter.

Hodge, Carleton T. 1970. The linguistic cycle. Language Sciences 13: 1-7.

Hopper, Paul J. 1996. Some recent trends in grammaticalization. Annual Review of Anthropology 25. 217-236.

Hopper, Paul J. \& Elizabeth C. Traugott. 2003. Grammaticalization. (Cambridge Textbooks in Linguistics). Cambridge: Cambridge University Press.

Hulst, Harry van der \& Jerome van der Weijer. 1995. Vowel harmony. In John Goldsmith (ed.) The Handbook of Phonological Theory, 495-534. Oxford: Basil Blackwell, Ltd.

Hulst, Harry van der \& B. Elan Dresher. 1998. Head-dependent asymmetries in phonology: Complexity and visibility. Phonology 15. 317-352.

Humboldt, Wilhelm von 1822, "Über das Entstehen der grammatischen Formen und ihren Einfluß auf die Ideenentwicklung." Abhandlungen der Akademie der Wissenschaften zu Berlin.

Jespersen, Otto. 1922. Language: Its nature, development and origin. London: Allen and Unwin.

Keating, Patricia A. 1988. The phonology-phonetics interface. In Frederick J. Newmeyer (ed.) Linguistic Theory: Foundations. Vol. 1. Linguistics: The Cambridge Survey. Cambridge: Cambridge University Press. 281-302.

Kiggen, J. (1983). Non-voiced vowels in Turkana. Studies in African Linguistics.

Kitching, A.L. 1915. A handbook of the Ateso language. London: Society for Promoting Christian Knowledge.

Köhler, Oswin R. A. 1970. The early study of the Nilotic languages of the Sudan 1821-1900, Part 1; translated by Paul E. H. Hair and Roland C. Stevenson. 
Lehmann, Christian. 2002. Thoughts on grammaticalization, Second revised edition. Arbeitspapiere des Seminars für Sprachwissenschaft der Universität Erfurt, No. 9. Erfurt: Philosophische Fakultät.

Lesley-Neuman, Diane. 2007. ATR harmony in Karimojong: Justification for a stratal optimality theory. University of Colorado at Boulder thesis.

Lewis, M. Paul (ed.), 2009. Ethnologue: Languages of the world, 16th edn. Dallas, Tex.: SIL International. Online version: http://www.ethnologue.com/

Lieber, Rochelle.1987. An integrated theory of autosegmental processes. Albany: State University of New York Press.

Logiro, Peter \& Joyce Ilukori. 2007. A simplified Ngarimojong-English / English Ngarimojong dictionary. Kampala: Fountain Publishers.

Mantovani, M.A. 1963. An introduction to the Karimojong language. Gulu, Uganda: Catholic Press.

Meillet, Antoine. 1948. L'evolution des formes grammaticales. In Antoine Meillet (ed.) Linguistique historique et linguistique générale. 130-148. Paris: Champion. First published in Scientia 12(26) [1912].

Noske, Manuela. 2000. [ATR] Harmony in Turkana: A case of Faith Suffix $>>$ Faith

Root. Natural Language and Linguistic Theory 18. 771-812.

Novelli, Bruno. 1985. A grammar of the Karimojong language. Berlin: Dietrich Reimer Verlag.

Novelli, Bruno. 1987. Small grammar of the Karimojong language. Verona, Italy: Verona Fathers.

Odden, David. 1993. Interaction between modules in lexical phonology. In Sharon Hargus and Ellen Kaisse (eds.) Studies in Lexical Phonology, 111-143. New York: Academic Press.

Pierrehumbert, Janet, Mary E. Beckman, \& Robert Ladd. 2000. Conceptual foundations of phonology as a laboratory science. In Noel Burton-Roberts, Philip Carr \& Gerard Docherty (eds.) Phonological Knowledge: Conceptual and Empirical issues, 273-303. Oxford, UK: Oxford University Press.

Recasens, D. \& Espinosa, Aina. 2002. Relating vocalic assimilatory processes to patterns of consonant-to-vowel-co-articulation: Evidence for the alveolar trill and dark [1]. Paper presented at 'ratics' 2: International Workshop on Sociolinguistic, Phonetic and Phonological Characteristics of/r/. Université Libre, Brussels. 
Schröder, Helga \& Martin Schröder. 1984. The Toposa verb. Occasional Papers in the Study of Sudanese Languages 5, 1-47.

Siewierska, Anna. 2004. Person. Cambridge: Cambridge University Press.

Traugott, Elizabeth Closs \& Bernd Heine. 1991. Approaches to grammaticalization. 2 Vols. Amsterdam: John Benjamins Publishing Company.

Trigo, Loren. 1991. On pharynx-larynx interactions. Phonology 8. 113-136.

Tucker, A.N. (1975). Voice quality in African languages. In Directions of Sudanese Linguistics and Folklore: International Conference on Language and Literature in Sudan, 44-57. Khartoum: Khartoum University Press and The Institute for African and Asian Studies at Khartoum University.

Vossen, Rainer. 1982. The Eastern Nilotes: Linguistic and historical reconstructions. Berlin: Dietrich Reimer Verlag.

Westbury, John R. 1979. Aspects of Temporal Control of Voicing in Consonant Clusters in English. MS. University of Texas at Austin.

Westbury, John R. 1983. Enlargement of the supraglottal cavity and its relation to stop consonant voicing. Journal of the Acoustical Society of America 73(4). 13221336.

Westbury, John R. \& Patricia Keating. 1986. On the naturalness of stop consonant voicing. Journal of Linguistics 22. 145-166.

Westermann, Diedrich \& Ida Ward. 1933. Practical phonetics for students of African languages. London: Oxford University Press for the International African Institute.

Wunderlich, D. \& Fabri, R.(1994) Wunderlich, D. and Fabri, R. (1994). Minimalist morphology: An approach to inflection. Zeitschrift für Sprachwissenschaft 20. 236-294.

Diane Lesley-Neuman

Utrecht Institute of Linguistics

D.Lesley-Neuman@uu.nl
Accepted: 28 June 2011

Revisions: 6 April 2012 